Portland State University

PDXScholar

$7-1-2010$

\title{
Long-Term Evaluation of Individualized Marketing Programs for Travel Demand Management
}

Jennifer Dill

Portland State University, jdill@pdx.edu

Cynthia D. Mohr

Portland State University

Follow this and additional works at: https://pdxscholar.library.pdx.edu/usp_fac

Part of the Urban Studies and Planning Commons

Let us know how access to this document benefits you.

\section{Citation Details}

Jennifer Dill and Cynthia Mohr. Long-term evaluation of individualized marketing programs for travel demand management. OTREC-RR-10-08. Portland, OR: Transportation Research and Education Center (TREC), 2010. http://dx.doi.org/10.15760/trec.132

This Technical Report is brought to you for free and open access. It has been accepted for inclusion in Urban Studies and Planning Faculty Publications and Presentations by an authorized administrator of PDXScholar. Please contact us if we can make this document more accessible: pdxscholar@pdx.edu. 


\section{SOTREC}

FINAL REPORT

\section{Long-term evaluation of individualized marketing programs for travel demand management}

OTREC-RR-10-08

July 2010 



\section{LONG-TERM EVALUATION OF INDIVIDUALIZED MARKETING PROGRAMS FOR TRAVEL DEMAND MANAGEMENT}

\section{FINAL RESEARCH REPORT \\ OTREC-RR-10-08}

by

Jennifer Dill, Ph.D.

Cynthia Mohr, Ph.D.

Portland State University

for

Oregon Transportation Research

and Education Consortium (OTREC)

P.O. Box 751

Portland, OR 97207

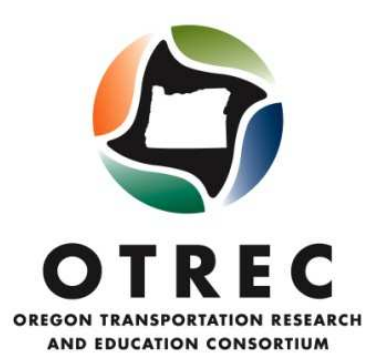

July 2010 



\begin{tabular}{|c|c|c|c|c|}
\hline \multicolumn{5}{|c|}{ Technical Report Documentation Page } \\
\hline $\begin{array}{l}\text { 1. Report No. } \\
\text { OTREC-RR-10-08 }\end{array}$ & \multicolumn{2}{|c|}{ 2. Government Accession No. } & \multicolumn{2}{|c|}{ 3. Recipient's Catalog No. } \\
\hline \multirow{2}{*}{\multicolumn{3}{|c|}{$\begin{array}{l}\text { 4. Title and Subtitle } \\
\text { Long term evaluation of individualized marketing programs for } \\
\text { travel demand management }\end{array}$}} & \multicolumn{2}{|c|}{$\begin{array}{l}\text { 5. Report Date } \\
\text { July } 2010\end{array}$} \\
\hline & & & \multicolumn{2}{|c|}{ 6. Performing Organization Code } \\
\hline \multicolumn{3}{|c|}{$\begin{array}{l}\text { 7. Author(s) } \\
\text { Jennifer Dill, Ph.D. } \\
\text { Cynthia Mohr, Ph.D. }\end{array}$} & \multicolumn{2}{|c|}{ 8. Performing Organization Report No. } \\
\hline \multirow{2}{*}{\multicolumn{3}{|c|}{$\begin{array}{l}\text { 9. Performing Organization Name and Address } \\
\text { Center for Urban Studies/Center for Transportation Studies } \\
\text { Portland State University } \\
\text { PO Box } 751 \\
\text { Portland, OR } 97201-0751\end{array}$}} & \multicolumn{2}{|c|}{ 10. Work Unit No. (TRAIS) } \\
\hline & & & \multicolumn{2}{|c|}{ 11. Contract or Grant No. } \\
\hline & \multicolumn{2}{|c|}{ 13. Type of Report and Period Covered } \\
\hline \multicolumn{3}{|l|}{$\begin{array}{l}\text { Oregon Transportation R } \\
\text { P.O. Box } 751\end{array}$} & \multicolumn{2}{|c|}{ 14. Sponsoring Agency Code } \\
\hline \multicolumn{5}{|l|}{ 15. Supplementary Notes } \\
\hline \multicolumn{5}{|c|}{$\begin{array}{l}\text { 16. Abstract } \\
\text { This research examines the use of individualized marketing as a transportation demand } \\
\text { management (TDM) strategy, using the City of Portland's SmartTrips program. This research } \\
\text { project has two specific aims: (1) to evaluate whether the benefits of these individualized } \\
\text { marketing programs continue to at least one year after the project ends; and (2) to examine } \\
\text { whether the theory of planned behavior (TPB) can help explain the behavior changes identified. } \\
\text { Surveys of residents conducted one or two years after the original program found that the share of } \\
\text { daily trips made driving alone, walking, and bicycling were comparable to that found in the } \\
\text { previous follow-up surveys, still significantly lower (for driving alone) or higher (for walking and } \\
\text { bicycling) than the pre-surveys. This may indicate that the SmartTrips program was effective at } \\
\text { changing behavior for a longer time period than previously measured. The theory of planned } \\
\text { behavior (TPB) models were effective at explaining travel behavior. The models showed that } \\
\text { attitudes, social norms, and perceived behavioral control explain a large share (45-55\%) of the } \\
\text { variance in travel behavior. The relative influence of each component of the model differed some } \\
\text { by mode. } \\
\text { The findings support previous research that individualized marketing programs can be effective at } \\
\text { changing people's travel behavior. The findings indicate that the benefits of the programs may } \\
\text { extend beyond one year and up to at least two years. However, the research also found that the } \\
\text { programs may not be as effective in environments that are less conducive to walking, bicycling, } \\
\text { and transit. The research also found that that attitudes, norms, and perceptions play a large role in } \\
\text { travel decisions. To be most effective, individualized marketing programs need to influence these } \\
\text { factors, though efforts that focus on social norms to influence travel behavior may be less } \\
\text { effective than those that include attitudinal and behavioral control components. Sensitivity to } \\
\text { regional characteristics and the specific travel mode that is the target of interest is also warranted. }\end{array}$} \\
\hline \multicolumn{2}{|c|}{$\begin{array}{l}\text { 17. Key Words } \\
\text { Travel Demand Management, Theory of Planned Behavior, Marketing, } \\
\text { Individualized Marketing, Psychology }\end{array}$} & \multicolumn{3}{|c|}{$\begin{array}{l}\text { 18. Distribution Statement } \\
\text { No restrictions. Copies available from OTREC: } \\
\text { www.otrec.us }\end{array}$} \\
\hline 19. Security Classification (of this report) & & & of Pages & 22. Price \\
\hline
\end{tabular}




\section{ACKNOWLEDGEMENTS}

The authors wish to thank the City of Portland's Bureau of Transportation, particularly Dan Bower and Linda Ginenthal, for their intellectual and financial support of this project. Several graduate research assistants played important roles in the project, including Staci Wendt, Peter Collins, and Gretchen Luhr. The Portland State University's Survey Research Lab was instrumental in helping to design the survey instruments and carry out the phone surveys, and special thanks goes to Debi Elliott, Amber Johnson, and Tiffany Conklin

\section{DISCLAIMER}

The contents of this report reflect the views of the authors, who are solely responsible for the facts and the accuracy of the material and information presented herein. This document is disseminated under the sponsorship of the U.S. Department of Transportation University Transportation Centers Program in the interest of information exchange. The U.S. Government assumes no liability for the contents or use thereof. The contents do not necessarily reflect the official views of the U.S. Government or the City of Portland. This report does not constitute a standard, specification, or regulation. 


\section{TABLE OF CONTENTS}

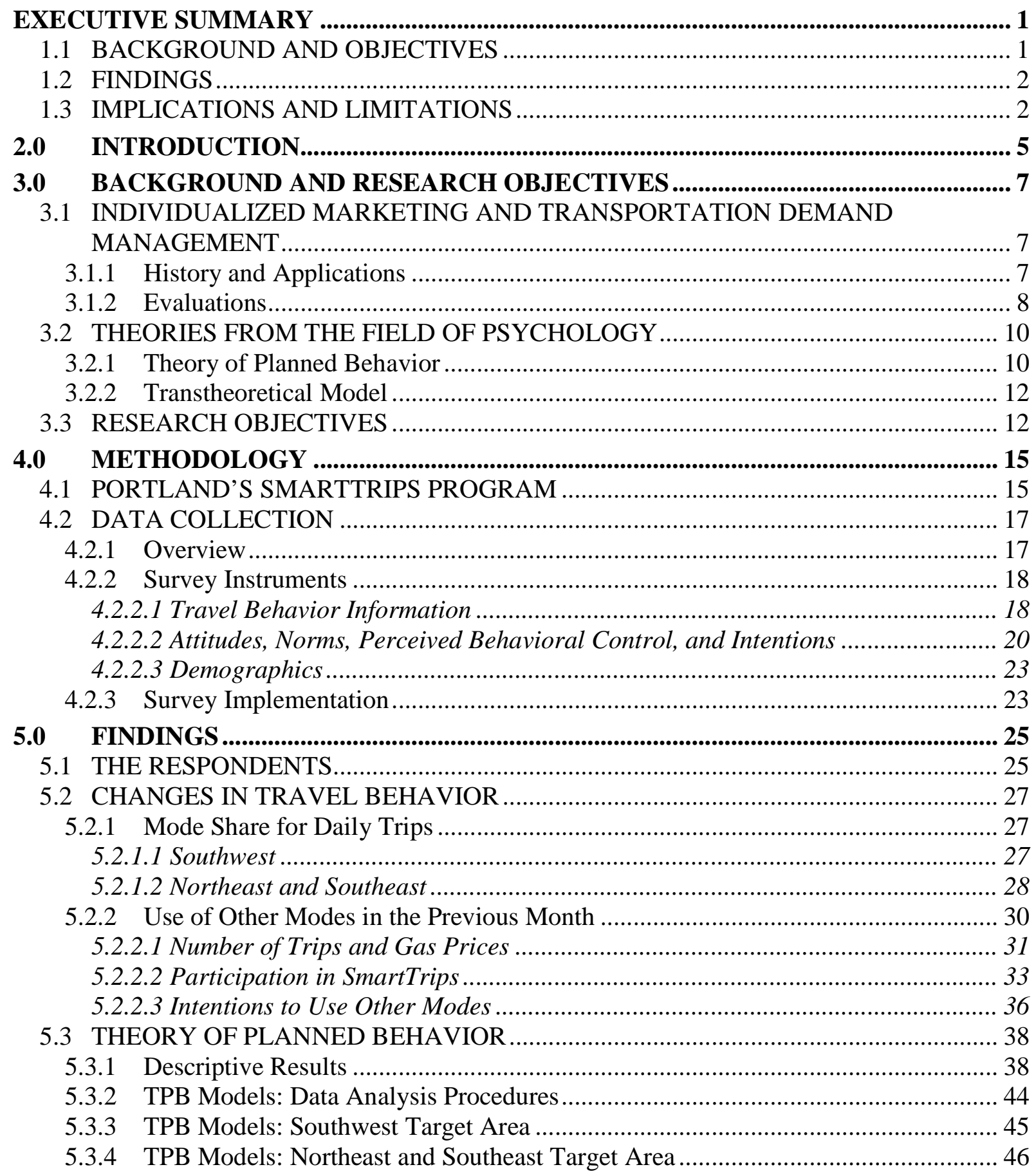


6.0 CONCLUSIONS …….................................................................................... 49

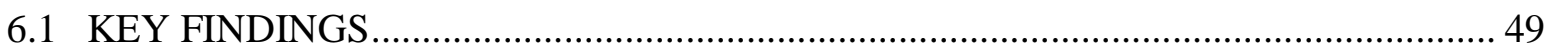

6.1.1 Effectiveness of Individualized Marketing ……………………………………..... 49

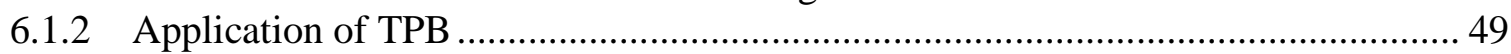

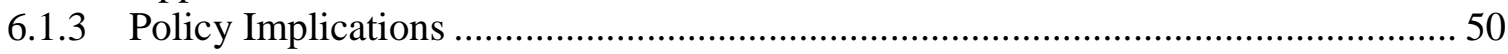

6.2 LIMITATIONS AND FUTURE RESEARCH.......................................................... 50

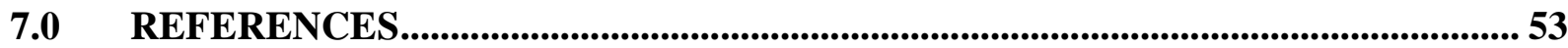

8.0 APPENDIX: SURVEY QUESTIONNAIRES...............................................................5 57

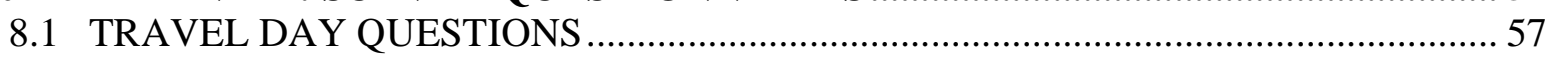

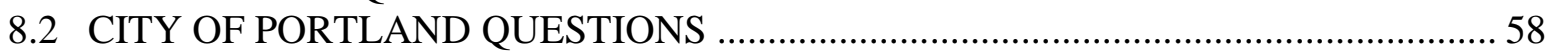

8.3 PSU BELIEFS AND ATTITUDE QUESTIONS ......................................................59

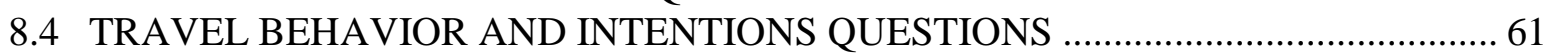

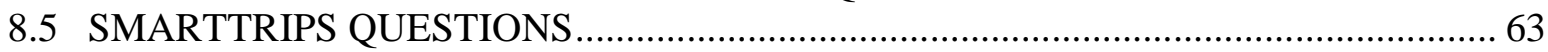

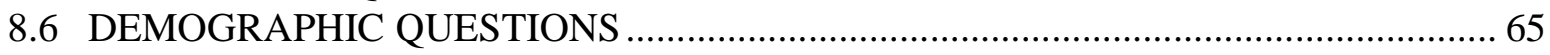




\section{LIST OF TABLES}

Table 1 Results from Individualized Marketing TDM Projects in the United States.................. 9

Table 2 Results from Individualized Marketing TDM Projects in Australia............................... 10

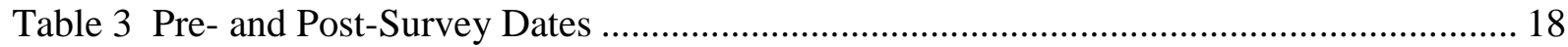

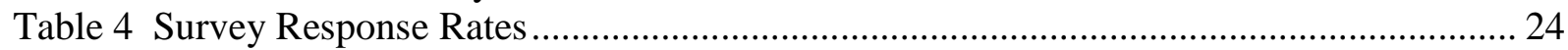

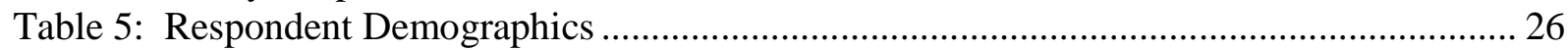

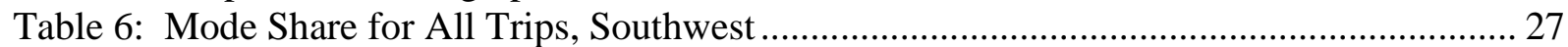

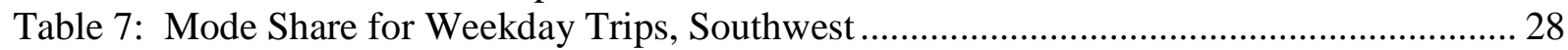

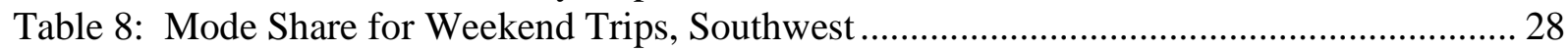

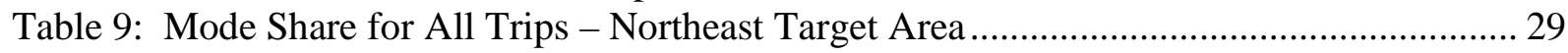

Table 10: Mode Share for All Trips - Southeast Target Area ..................................................29

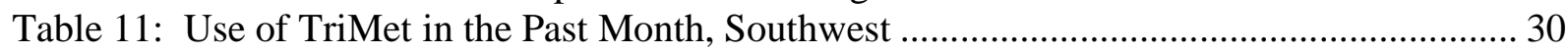

Table 12: Walking from Home in the Past Month, Southwest ................................................. 30

Table 13: Biking from Home in the Past Month, Southwest ...................................................... 31

Table 14 Gas Prices During Pre- and Post-Survey Dates ......................................................... 31

Table 15: Average Number of Trips per Day per Person, Southwest ...................................... 32

Table 16: Changes in Driving and Role of Gas Prices, Southwest........................................... 33

Table 17: Changes in Driving and Role of Gas Prices, Northeast and Southeast ....................... 33

Table 18: Differences between in Ordering SmartTrips Materials by Pre-Survey Travel

Behavior, Southwest

Table 19: Differences between Respondents Who Did and Did Not Order SmartTrips Materials and Post-Survey Travel Behavior, Southwest

Table 20: Use of Transit, Walking and Bicycling in the Past Month - Respondents Who Did and

Did Not Order SmartTrips Materials, Northeast and Southeast .............................................. 35

Table 21: Trips by Mode - Respondents Who Did and Did Not Order SmartTrips Materials.... 36

Table 22: Intentions for Walking for Daily Travel, Southwest ................................................... 37

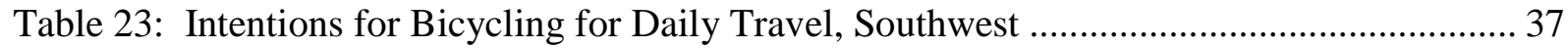

Table 24: Intentions for Taking Transit for Daily Travel, Southwest ...................................... 38

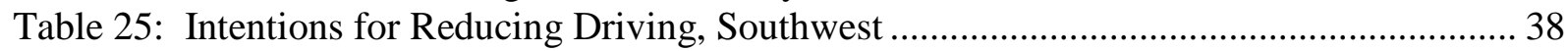

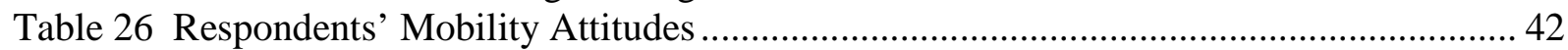

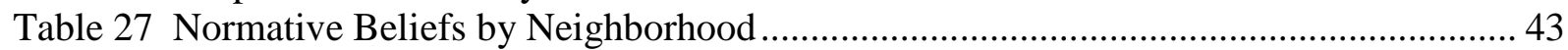

Table 28 Perceived Behavioral Control by Neighborhood ........................................................ 44

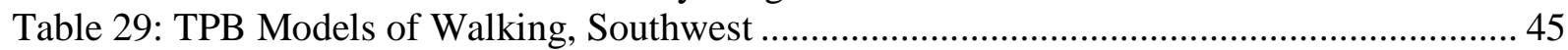

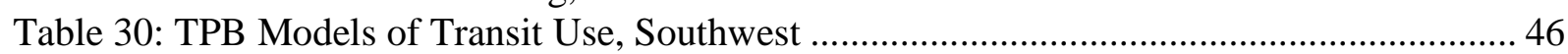

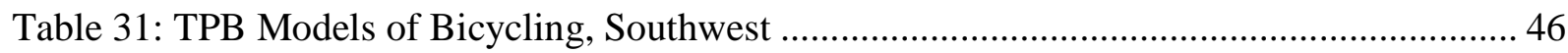

Table 32: TPB Models of Walking, Northeast and Southeast compared to Southwest ............... 47

Table 33: TPB Models of Transit Use, Northeast and Southeast compared to Southwest........... 48

Table 34: TPB Models of Bicycling, Northeast and Southeast compared to Southwest.............. 48 


\section{LIST OF FIGURES}

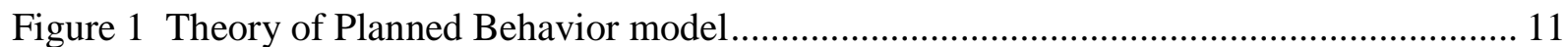

Figure 2 Map of City of Portland SmartTrips Target Areas, 2006-2008................................... 16

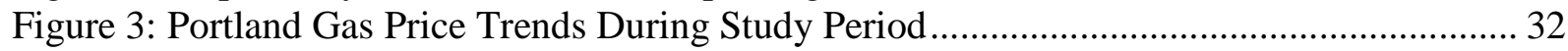

Figure 4 Respondents Attitudes towards Walking and Bicycling .......................................... 40

Figure 5 Respondents Attitudes towards Traveling by Car and Transit ................................... 41 


\section{EXECUTIVE SUMMARY}

\subsection{BACKGROUND AND OBJECTIVES}

With increasing concerns over traffic congestion, fossil fuel use, air pollution and livability, coupled with severe constraints on funding for new transportation infrastructure, cities and regions are increasingly looking to a wider range of options to address transportation problems. Transportation (or travel) demand management (TDM) is one of those options used over the past $30+$ years with varying success. Historically in the U.S., programs have focused on commuter trips and employers or broad-based awareness campaigns. More recently, the concepts of social and individualized marketing are being applied to TDM at the household level and for all types of trips.

Starting in 2003, the City of Portland has undertaken a series of household-based, individualized marketing programs aimed at reducing drive-alone trips. The programs are based on the TravelSmart@ concept originated by Socialdata, a German-based company. TravelSmart has been used extensively in Australia, where it has been shown to significantly reduce drive-alone trips by employing in-depth surveying and targeted marketing. The City's program is currently called SmartTrips. With each program, the City conducted pre- and post-surveys of a random sample of neighborhood residents. The post-surveys were conducted immediately following the project. The data from 2003 through 2007 showed a reduction in the share of trips made driving alone and some increases in the share of trips made by other modes. However, the City has not conducted evaluations that assess whether these changes are sustained beyond one or two months after the project ends. Such long-term evaluations are rare for programs in other countries as well.

In addition, few of the TravelSmart and none of the City's SmartTrips evaluations have closely examined the mechanisms of behavior change. Transportation researchers traditionally look at travel behavior through the lens of microeconomic theories based upon the belief that people want to maximize utility and minimize costs, including travel time. However, these theories don't adequately explain all of the variation in people's travel decisions. Because the programs are attempting to change people's behavior it would seem appropriate to draw upon the field of psychology, which has a long history of studying behavior change and decision making. One widely applied model from psychology is the theory of planned behavior (TPB). The TPB considers behavior as a function of a person's attitudes, social norms and perceived behavioral control. The TPB allows for the estimation of relative contributions of each predictive factor, which provides marketing programs guidance in directing program efforts.

This research project has two specific aims: (1) to evaluate whether the benefits of these individualized marketing programs continue at least one year after the project ends; and (2) to examine whether the theory of planned behavior can help explain the behavior changes identified. To answer these questions, we conducted a pre- and post-survey of a panel of residents in the SmartTrips target area for 2008 (Southwest Portland), and additional postsurveys of residents in the target areas for 2006 (Northeast) and 2007 (Southeast). These data supplemented data from surveys previously conducted by the City of Portland. 


\subsection{FINDINGS}

The pre- and post-surveys of the panel of residents in the Southwest target area found few shifts in travel behavior consistent with the intentions of the SmartTrips program. There was a significant drop in the share of weekday trips made driving alone. However, some of this drop may be attributed to an increase in gas prices between the two surveys. The daily trip data indicated that there may have been an increase in walking, though the difference was not statistically significant. There was, however, a significant increase in the share of respondents who said they had biked in the past month.

The findings from the Northeast and Southeast target areas were more positive with respect to the SmartTrips program. Those surveys found that the share of daily trips made driving alone, walking, and bicycling were comparable to that found in the previous follow-up surveys, still significantly lower (for driving alone) or higher (for walking and bicycling) than the pre-surveys. This may indicate that the SmartTrips program was effective at changing behavior for a longer time period than previously measured. Finally, the differences between people who had participated in the SmartTrips program, measured by whether they ordered program materials, and those that did not indicates that the program may have contributed to the changes in travel behavior.

The theory of planned behavior (TPB) models were effective at explaining travel behavior. The models showed that attitudes, social norms, and perceived behavioral control explain a large share $(45-55 \%)$ of the variance in travel behavior. The relative influence of each component of the model differed some by mode. For example, in the Southwest target area, attitudes had the largest influence on bicycling, while perceived behavioral control seemed more important in predicting walking behavior. In most cases, the models indicated that social norms do not influence behavior very much.

Some of the differences in the changes in travel mode between the three target areas may be explained by components of the TPB. Residents in the Northeast and Southeast target areas scored higher on several of the indicators of positive attitudes towards walking and bicycling, social norms related to using other modes and perceived behavioral control for using transit, walking, and bicycling. The data from the Southwest panel, however, did not indicate many significant changes in these factors in the direction intended by the program. In other words, the survey did not show that the program affected these factors significantly.

\subsection{IMPLICATIONS AND LIMITATIONS}

The findings from the Northeast and Southeast target areas support previous research that individualized marketing programs can be effective at changing people's travel behavior. The findings indicate that the benefits of the programs may extend beyond one year and up to at least two years. However, the findings from the Southwest target area indicate that the programs may not be as effective in all environments. The programs may be more effective in neighborhoods with a physical environment more conducive to walking, bicycling, and transit. Several of the differences in perceived behavioral control were related to the physical environment, such as having places within walking and biking distance. Public policy and investment can influence the location of destinations near residential areas. In addition, the benefits of investing in making a 
community more walkable and bikeable and improving transit service might be increased through the use of such marketing programs.

The research also found that attitudes, norms, and perceptions play a large role in travel decisions. To be most effective, individualized marketing programs need to influence these factors. However, based on the findings, efforts that focus on social norms to influence travel behavior may be considerably less effective than those that include attitudinal and behavioral control components. Sensitivity to regional characteristics and the specific travel mode that is the target of interest also is warranted. Overall, the TPB demonstrates the efficacy of combining all three components to maximally influence behavior change. This research did not detect changes in these factors before and after the program and, therefore, cannot shed light on how to influence those factors. However, the research did show which factors had a larger effect on the decision to use different travel modes. This can provide some guidance on which factors to target in marketing programs.

There are several limitations that arose with the survey data and methods. For example, the lack of findings of significant changes or differences in the Southwest panel survey may be due to the sample size $(\mathrm{n}=288)$. More analysis of the data is necessary to explore what roles the physical environment and access to infrastructure (e.g., sidewalks, bike lanes, transit) and destinations (e.g., shops and restaurants). Additional analysis also should include weather as a factor. This can be done by developing measures of each respondent's environment using their home location, which was collected on the survey. These variables, along with demographics, can then be added to the models with the TPB variables to understand the relative contribution of each factor. 


\subsection{INTRODUCTION}

With increasing concerns over traffic congestion, fossil fuel use, air pollution and livability, coupled with severe constraints on funding for new transportation infrastructure, cities and regions are increasingly looking to a wider range of options to address transportation problems. Transportation (or travel) demand management (TDM) is one of those options used over the past $30+$ years with varying success. Historically in the U.S., programs have focused on commuter trips and employers or broad-based awareness campaigns. More recently, the concepts of social and individualized marketing are being applied to TDM at the household level and for all types of trips.

Starting in 2003, the City of Portland has undertaken a series of household-based, individualized marketing programs aimed at reducing drive-alone trips. The programs are based on the TravelSmart $\odot$ concept originated by Socialdata, a German-based company. TravelSmart has been used extensively in Australia, where it has been shown to significantly reduce drive-alone trips by employing in-depth surveying and targeted marketing. The TravelSmart concept was first tested in the U.S. in 2003 in Portland's Hillsdale neighborhood. Those results were positive, and the City implemented TravelSmart the next year along the Interstate corridor. The following year the City developed its own program, SmartTrips, based on the TravelSmart concept. SmartTrips programs targeted Eastside Portland in 2005, Northeast Portland in 2006, Southeast Portland and Milwaukee in 2007, and Southwest Portland in 2008. Residents in the targeted neighborhoods receive personalized information from the City about different travel options (walking, cycling, transit, and car sharing) and can participate in guided walks, rides, and other events. The program is based on the strategy of showing people how to use alternative modes and rewarding them for doing so.

With all of these programs, the City conducted pre- and post-surveys of a random sample of neighborhood residents. The post-surveys were conducted immediately following the project. The surveys collected data about all of the trips a person made that day. The data from 2003 through 2007 showed a reduction in the share of trips made driving alone and some increases in the share of trips made by other modes. However, the City has not conducted evaluations that assess whether these changes are sustained beyond one or two months after the project ends. Such long-term evaluations are rare for programs in other countries as well.

In addition, few of the TravelSmart and none of the City's SmartTrips evaluations have closely examined the mechanisms of behavior change. Transportation researchers traditionally look at travel behavior through the lens of microeconomic theories based upon the belief that people want to maximize utility and minimize costs, including travel time. However, these theories don't adequately explain all of the variation in people's travel decisions. Because the programs are attempting to change people's behavior, it would seem appropriate to draw upon the field of psychology, which has a long history of studying behavior change and decision making. One widely applied model from psychology is the theory of planned behavior (TPB). The TPB considers behavior as a function of the person's attitudes, social norms and perceived behavioral control. The TPB allows for the estimation of relative contributions of each predictive factor, which provides marketing programs guidance in directing program efforts. 
This research project has two specific aims: (1) to evaluate whether the benefits of these individualized marketing programs continue at least one year after the project ends; and (2) to examine whether the theory of planned behavior can help explain the behavior changes identified. This report presents results of the research, which included multiple surveys of residents in three Portland neighborhoods where SmartTrips was implemented in 2006, 2007, and 2008. 


\subsection{BACKGROUND AND RESEARCH OBJECTIVES}

\subsection{INDIVIDUALIZED MARKETING AND TRANSPORTATION DEMAND MANAGEMENT}

\subsubsection{History and Applications}

Efforts in the U.S. to reduce motor vehicle travel can be traced back to World War II, when the U.S. government encouraged carpooling to deal with resource shortages (Ferguson 1997). However, the more comprehensive concept of transportation (or travel) demand management (TDM) did not arise until the 1970s, in response to oil supply shortages and the Clean Air Act (Meyer 1999). TDM generally aims to manage the volume of motor vehicle traffic, particularly in congested times and places, by either reducing demand or shifting it to non-congested locations or times. Demand can be reduced by shifting trips to other modes (carpooling, transit, walking, bicycling, etc.) or eliminating trips. It is often viewed as an alternative to increasing supply (i.e., building more road capacity) and is akin to utility programs that promote the purchase of energy-efficient light bulbs and appliances, rather than building more power plants.

Over time, the field has evolved to include additional motivations (e.g., health and obesity) and expanded targets (e.g., beyond work commute trips). The costs and effectiveness of individual TDM strategies vary significantly (Meyer 1999). One area that has gained attention recently is individualized marketing. Such programs aim to supply individuals with information and messages that are targeted to their needs and situation, rather than mass marketing campaigns that blanket areas with broad messages. The first significant applications of individualized marketing to TDM were in Europe, followed by Australia. More recently, the concept has been applied in the U.S.

One of the earliest, if not the first, individualized marketing programs applied to TDM was conducted by Werner Brog and his company Socialdata. Brog began with experiments in what he termed "soft policies" to promote transit use in a handful of German cities. This was expanded to 13 European countries, in cooperation with the International Association of Public Transport (Brog 1998). In these applications, all households within a target area were contacted and then classified based upon their potential interest in using transit. There were three main groups - interested (I), regular users (R), and not interested $(\mathrm{N})$. Socialdata branded their specific process as IndiMark ${ }^{(B r o g}$ and Barta 2007).

The concept was next applied in several locations in Australia, where it was labeled TravelSmart. Some of these programs were implemented and evaluated by Werner Brog and Socialdata, while others were undertaken by Australian government agencies. TravelSmart has been used in many Australian cities at the neighborhood scale targeting households, as well as employment sites, government agencies, and universities. The neighborhood applications often target a population of 10,000-40,000 households. 
The first TravelSmart application in the U.S. was in 2003 in Portland's Hillsdale neighborhood. The City of Portland hired Socialdata to conduct the program. Those results were positive, and the City implemented TravelSmart the next year along the Interstate corridor. In 2005, the City developed its own program, SmartTrips, based on the TravelSmart concept. SmartTrips programs targeted Eastside Portland in 2005, Northeast Portland in 2006, and Southeast Portland and Milwaukee in 2007, and Southwest Portland in 2008. Residents in the targeted neighborhoods received personalized information from the City about different travel options (walking, cycling, transit, and car sharing) and could participate in guided walks, rides, and other events.

Following the initial success of TravelSmart in Portland, Werner Brog and Socialdata were contracted to implement and evaluate the Federal Transit Administration's (FTA) Individualized Marketing Demonstration Programs (IMDP). Programs were conducted in 2004 and 2005 in Bellingham, WA; Cleveland, OH; Durham, NC; and Sacramento, CA. Since then, several additional U.S. cities are implementing programs modeled after the City of Portland's SmartTrips program.

\subsubsection{Evaluations}

Most of the programs described above have been evaluated to assess changes in travel behavior. Information on several of the evaluations is shown in Table 1 (United States) and Table 2 (Australia). The evaluations usually include before-and-after surveys using self-reported travel information. One evaluation also used GPS to collect data and another collected odometer readings. The majority of evaluations identified through this research reported a significant reduction in personal vehicle travel. A review of several household-based projects conducted in Australia from 2001-2005 found that "larger household projects routinely show decreases in car use of 4-15\%, and rises in the use of walking, cycling, and public transport" (Australian Greenhouse Office 2005).

With one exception, the post-intervention data collection for the evaluations listed in Table 1 and Table 2 occurred within one to eight months after the end of the intervention. The evaluation of the South Perth project conducted in 2000 included evaluations in 2000, 2001, 2002, and 2004. The agency sponsoring the evaluations concluded that there was "little loss of impact after two and a half years even though no reinforcement of the behaviour change was undertaken" (Australian Greenhouse Office 2005). The share of trips made as a car driver was $60 \%$ before the intervention, $52 \%$ immediately afterwards and 54\% in 2004. One long-term evaluation of a project in Cambridge, Australia, using bus ridership as a measure showed continued increases in ridership over three years (Australian Greenhouse Office 2005). 
Table 1 Results from Individualized Marketing TDM Projects in the United States

\begin{tabular}{|c|c|c|c|}
\hline Location & Date & Evaluation Information & Results \\
\hline $\begin{array}{l}\text { Portland, OR - } \\
\text { Hillsdale }\end{array}$ & 2003 & $\begin{array}{l}\text { Conducted by Socialdata. } \\
\text { Before surveys in April-May. After } \\
\text { surveys one year later. Repeated cross- } \\
\text { sectional survey, with control group. }\end{array}$ & $9 \%$ reduction in drive-alone trips \\
\hline $\begin{array}{l}\text { Portland, OR - } \\
\text { Interstate }\end{array}$ & 2004 & $\begin{array}{l}\text { Conducted by Socialdata. } \\
\text { Before surveys in April-May. After } \\
\text { surveys one year later. Repeated cross- } \\
\text { sectional survey, with control group. }\end{array}$ & $9 \%$ reduction in drive-alone trips \\
\hline Portland, OR - East & 2005 & $\begin{array}{l}\text { Conducted by Davis, Hibbits \& Midgall } \\
\text { and City of Portland. Before survey in } \\
\text { February-March, } n=300 \text {. After survey in } \\
\text { October, } n=300 \text {. }\end{array}$ & $8.6 \%$ reduction in drive-alone trips \\
\hline $\begin{array}{l}\text { Portland, OR - } \\
\text { Northeast }\end{array}$ & 2006 & $\begin{array}{l}\text { Conducted by Campbell DeLong and } \\
\text { City of Portland. Before survey in March, } \\
n=300 \text {. After survey in September, } \\
n=300 \text {. Control group included. }\end{array}$ & $12.8 \%$ reduction in drive-alone trips \\
\hline $\begin{array}{l}\text { Portland, OR - } \\
\text { Southeast }\end{array}$ & 2007 & $\begin{array}{l}\text { Conducted by Campbell DeLong and } \\
\text { City of Portland. Before surveys in } \\
\text { March }(n=300) \text { and September } 2006 \\
(n=600) \text {. After survey in September 2007, } \\
n=600 \text {. }\end{array}$ & $9.4 \%$ reduction in drive-alone trips \\
\hline Cleveland, $\mathrm{OH}$ & 2005 & $\begin{array}{l}\text { Conducted by MELE Associates, Inc. and } \\
\text { Socialdata. } \\
\text { Before survey in February }(n=1,583) \text {. } \\
\text { After survey in June }(n=1,814) .\end{array}$ & $4 \%$ reduction in drive-alone car trips \\
\hline Durham, NC & 2005 & $\begin{array}{l}\text { Conducted by MELE Associates, Inc. and } \\
\text { Socialdata. } \\
\text { Before survey in October-November } \\
2004(n=1,043) \text {. After survey in May- } \\
\text { June }(n=1,174) \text {. }\end{array}$ & $7 \%$ reduction in drive-alone car trips \\
\hline Sacramento, CA & 2005 & $\begin{array}{l}\text { Conducted by MELE Associates, Inc. and } \\
\text { Socialdata. } \\
\text { Before survey }(n=1,288) \text { and after survey } \\
(n=1,524) \text {. }\end{array}$ & $2 \%$ reduction in drive-alone car trips \\
\hline Bellingham, WA & 2004 & $\begin{array}{l}\text { Conducted by MELE Associates, Inc. and } \\
\text { Socialdata. } \\
\text { Before surveys in May ( } \mathrm{n}=988 \text { in target } \\
\text { areas, } 1,208 \text { in control). After survey in } \\
\text { September-October }(\mathrm{n}=1,174) \text {. }\end{array}$ & $8 \%$ reduction in drive-alone car trips \\
\hline
\end{tabular}

Sources: (Portland Office of Transportation 2007; Socialdata America 2005; City of Portland Office of Transportation 2005, 2006; MELE Associates 2006) 
Table 2 Results from Individualized Marketing TDM Projects in Australia

\begin{tabular}{|c|c|c|c|}
\hline Location & Date & Evaluation Information & Results \\
\hline Adelaide & 2002 & $\begin{array}{l}\text { Conducted by Booz Allen Hamilton and } \\
\text { Market Equity. } \\
\text { Before survey in October, after survey in } \\
\text { April. 3-day travel diary and odometer } \\
\text { survey. Sample included } 154 \text { program } \\
\text { participants, } 242 \text { non-participants in area, } \\
248 \text { people in control neighborhoods. }\end{array}$ & No significant change in car use \\
\hline Canberra pilot & 2001 & $\begin{array}{l}\text { Conducted by Taylor Nelson Sofres. } \\
\text { Surveys immediately before, one month } \\
\text { after and five months after. Control } \\
\text { group, } n=99 ; \text { Intervention group } n=57 \text {. }\end{array}$ & $\begin{array}{l}\text { Drop in vehicle kilometers traveled, } \\
\text { but several issues raised with } \\
\text { evaluation method. }\end{array}$ \\
\hline Canberra & 2004 & $\begin{array}{l}\text { Conducted by Univ. of Sydney. } \\
\text { Control group } n=87 \text {; Intervention group } \\
n=102 \text {. } \\
\text { Before survey in February-May, after } \\
\text { survey in July-October. Travel diary and } \\
\text { GPS. }\end{array}$ & $\begin{array}{l}\text { GPS showed that car-driver trips fell } \\
13.6 \% \text { in intervention group } \\
\text { compared to } 6.1 \% \text { drop in control } \\
\text { group. }\end{array}$ \\
\hline $\begin{array}{l}\text { South Perth, } \\
\text { Australia }\end{array}$ & 2000 & $\begin{array}{l}\text { Conducted by Socialdata } \\
\text { Repeated cross-section mail survey, } \\
n=1,454\end{array}$ & $14 \%$ reduction in drive-alone travel \\
\hline Subiaco, Perth & 2002 & $\begin{array}{l}\text { Conducted by Socialdata } \\
\text { Repeated cross-section mail survey, } \\
n=490\end{array}$ & $12 \%$ reduction in drive-alone travel \\
\hline Cambridge, Perth & 2002 & $\begin{array}{l}\text { Conducted by Socialdata } \\
\text { Repeated cross-section mail survey, } \\
n=1,030\end{array}$ & $12 \%$ reduction in drive-alone travel \\
\hline Marangaroo, Perth & 2003 & $\begin{array}{l}\text { Conducted by Socialdata } \\
\text { Panel survey, } n=580\end{array}$ & $4 \%$ reduction in drive-alone travel \\
\hline Melville, Perth & 2003 & $\begin{array}{l}\text { Conducted by Socialdata } \\
\text { Panel survey, } n=1,300\end{array}$ & $12 \%$ reduction in drive-alone travel \\
\hline Fremantle, Perth & 2004 & $\begin{array}{l}\text { Conducted by Socialdata } \\
\text { Panel survey, } n=1,302\end{array}$ & $7 \%$ reduction in drive-alone travel \\
\hline $\begin{array}{l}\text { Alamein line, } \\
\text { Melbourne }\end{array}$ & 2003 & $\begin{array}{l}\text { Conducted by Socialdata } \\
\text { Before survey (May) } n=1,126 \\
\text { After survey (October) } n=943\end{array}$ & $10 \%$ reduction in drive-alone travel \\
\hline Redlands, Brisbane & 2005 & $\begin{array}{l}\text { Conducted by Socialdata } \\
\text { Before survey (June) } n=2,357 \\
\text { After survey (October-November) } \\
n=2,831\end{array}$ & $11 \%$ reduction in drive-alone travel \\
\hline Brisbane pilot & 2001 & Conducted by Socialdata & $10 \%$ reduction in automobile use \\
\hline
\end{tabular}

Sources: (Australian Greenhouse Office 2005)

\subsection{THEORIES FROM THE FIELD OF PSYCHOLOGY}

\subsubsection{Theory of Planned Behavior}

SmartTrips, like other individualized or social marketing programs, aims to change human behavior. Rather than assuming that travel choices are only influenced by time and other costs, the program is based on a premise that with useful information and encouragement, people may change behavior. Given this starting point, it would be useful to employ theories of psychology 
in evaluating the programs, in addition to the traditional economic theories that provide the foundation for most travel behavior models. One such theory is the theory of planned behavior (TPB) developed by Icek Ajzen (Ajzen 1985; 1991).

The theory, as depicted in Figure 1, holds that behavior is guided by (1) a person's attitude toward the behavior, including the likely consequences of the behavior; (2) subjective norms, including the expectations of others; and (3) the person's perceived control over the behavior. Attitudes are people's favorable or unfavorable evaluative reactions to the behavior of interest. Subjective norms concern the perception of whether important others think the person should or should not perform the behavior of interest. Finally, perceived behavioral control is the extent to which people believe they have the skills and ability to enact the behavior. These factors determine the person's intention to behave in a certain way which, in turn, influences actual behavior, as long as the behavior is under the person's control. According to the model, attitudes and norms only influence behavior through intentions. However, perceived behavioral control both directly and indirectly (i.e., through intentions) influences behavior. The theory has been applied to a wide range of behaviors, including playing video games, voting, shoplifting, and gift giving. A meta-analysis of 161 studies published through 1997 using the theory found that TPB accounted for $27 \%$ of the variance in behavior (Armitage and Conner 2001).

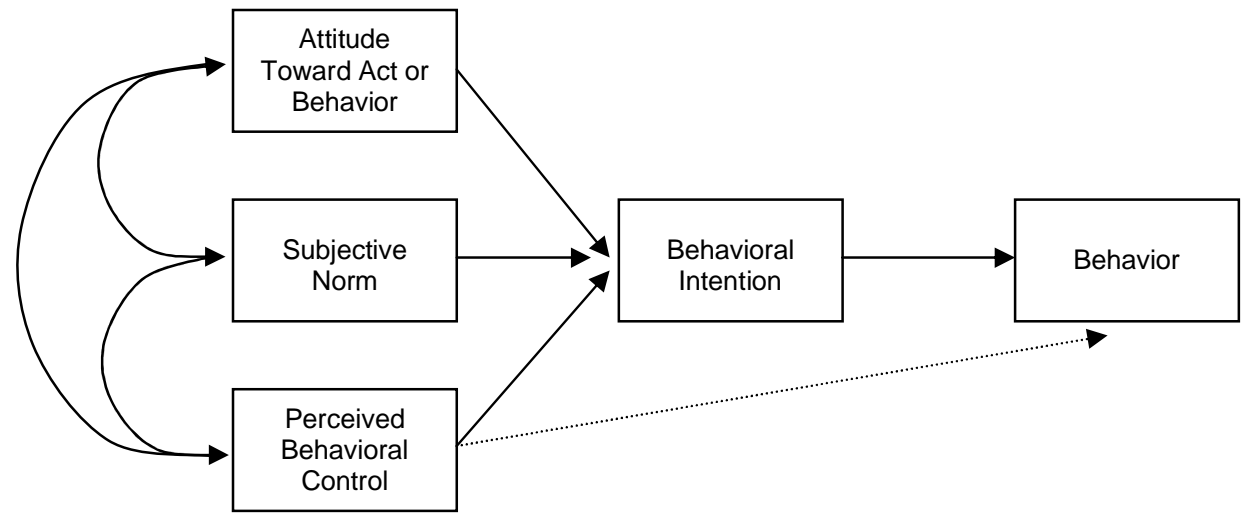

Source: Ajzen 1991

\section{Figure 1 Theory of Planned Behavior model}

Applying the TPB framework to an evaluation of an intervention attempting to change travel behavior can help explain why behavior change occurs (or not). It also offers information about the relative contributions of attitudes, norms and perceived behavioral control to the behavior of interest. This information can then be used to improve program effectiveness. Garling et al (1998) described how the theory could be useful in travel behavior research. Recently, a handful of transportation researchers have applied the theory to travel behavior and, in particular, to mode choice. For example, Bamberg et al (2003a) found the theory useful in explaining the effects of offering prepaid bus passes for university students. Bamberg et al (2003b) applied the theory to an intervention offering information and a transit pass to recent movers. Both studies were conducted in Germany, and found that the intervention influenced all three factors in the TPB, leading to behavior change. Beale and Bonsall (2007) applied the theory to a bus marketing 
program in the United Kingdom and suggested that "it would now be useful to explore the effect of persuasive messages on people's travel behaviour by explicit assessment of the variables in the TPB" framework (p. 285). The TPB also has been successfully applied to exercise behavior (Blanchard et al. 2008; Norman \& Conner 2005; Kiviniemi, Voss-Humke, \& Seifert 2007). Indeed, two comprehensive reviews (one meta-analysis) of empirical studies of exercise provided validation of the TPB (Blue 1995; Hausenblas, Carron, and Mack 1997).

\subsubsection{Transtheoretical Model}

The transtheoretical model (TTM) is the most widely applied stage theory and includes five distinct stages of health behavior change (Prochaska et al. 1994; Prochaska, DiClemente \& Norcross, 1992). According to the model, people in the precontemplation stage have no intention to change their current behavior or awareness that there might be a need for change. People who are in contemplation recognize that there might be a need for change and are thinking about it, but have not made a commitment to change. At the point where people intend to make a change and are beginning to enact steps to initiate change, they are in the preparation stage. Once actual health behavior change has begun, people are considered to be in the action stage. Finally, at the point at which people have engaged in the health behavior change for at least six months or more and are actively working to prevent relapse or reinforce the gains that have been made, they are considered in the maintenance stage. A critical point of the TTM is the notion that in the process of change, individuals can cycle through multiple times, experiencing relapses and subsequent recommitments to change, before ultimately achieving long-term health behavior change (Prochaska et al., 1992).

Further, overlapping each stage of the TTM is a decision-making model based on Janis and Mann's (Janis and Mann 1977), wherein the individual is weighing the pros and cons of adopting the new behavior change (Prochaska et al., 1994). Accordingly, at the precontemplation stage, the pros for adopting a healthier behavior should be outweighed by the cons of making a behavior change. As people move through the stages into action, the decisional balance changes such that at preparation the pros and cons are relatively equal and, at the action stage, the pros actually outweigh the cons. Prochaska et al. (Prochaska 1994) have validated this decisionmaking model in a wide range of behaviors, including exercise and weight control.

One major implication of the theory is that intervention efficacy is dependent upon the stage at which the target person is currently located (Armitage \& Arden, 2008), with interventions demonstrating greatest effectiveness for people in the preparation and action stages. Further, according to Prochaska et al. (1994) initial intervention efforts should aim to increase the pros of adopting the health behavior change.

\subsection{RESEARCH OBJECTIVES}

This research project has two separate, but complementary, aims:

(1) to evaluate whether the benefits of individualized marketing programs aimed at reducing private vehicle travel (e.g. SmartTrips) continue at least one year after the program ends; and 
(2) to examine whether the theory of planned behavior (TPB) can help explain the behavior changes identified.

These two objectives required a combination of surveys and survey designs. To answer the first question, we conducted random surveys of residents in two different neighborhoods where the City of Portland implemented SmartTrips. For one area, the survey occurred two years after the SmartTrips intervention. For the other, the survey was one year after the intervention. To answer the second question, we conducted pre- and post-surveys of a sample of residents in the neighborhood where the City implemented SmartTrips in 2008. Both of these surveys included several questions to gather data for the TPB model. The TPB questions were also included on the one- and two-year post-surveys for comparison purposes. 


\subsection{METHODOLOGY}

\subsection{PORTLAND'S SMARTTRIPS PROGRAM}

Each year since 2005, the city's Transportation Options Division has chosen a different target area in which to implement its SmartTrips program. The program is modeled after the TravelSmart programs developed by Socialdata and implemented by the City in 2003 and 2004. The primary goals of the program are to:

- Reduce drive-alone trips

- Reduce vehicle miles driven by area residents and employees

- Increase awareness and raise acceptability of all modes of travel

- Increase walking, biking, transit, carpooling, and car-sharing trips

- Increase neighborhood mobility and livability

(City of Portland Office of Transportation 2006)

The main difference between the original process used by Brog in TravelSmart and the City's SmartTrips program is the elimination of the segmentation step that uses a survey to characterize each household as I, R, or N. Instead, each household in the target area receives an initial mailing about the program with an order form. It could be assumed that anyone ordering materials could be characterized as interested (I) or regular users (R). Each year, the program may include a slightly different mix of components and events. The materials available for order typically include walking and biking maps, transit schedules, TransitTracker cards (for stop and arrival information), walking kits (with pedometers), biking kits, coupon books for local businesses, and incentives (e.g., an umbrella or bandana bike map). The materials also include information about events held in the neighborhood as part of the SmartTrips program. Events include organized bike rides and walks, bike clinics for women, senior strolls, bike light and youth helmet distribution, "smart living" classes, and the OptionsMobile - a mobile display with travel options information. Materials are delivered to residents by City staff on bicycles.

The program lasts about six months, not including evaluation and staff preparation time. In the first few weeks of the program (March and April), all residents receive at least two newsletters. Those ordering materials continue to receive regular newsletters with additional information and event listings. The City partners with businesses and other public agencies each year to support the program. For example, Kaiser Permanente has sponsored the Ten Toe Express Walking Campaign, local businesses supply coupons, and TriMet (Portland's transit agency) provides printed schedules. Organizations such as Shift to Bikes and Elders in Action get involved in promoting and organizing events.

The target areas for the SmartTrips programs in 2006, 2007, and 2008 are shown in Figure 2. In 2006, SmartTrips targeted the "Northeast Hub" area of about 24,000 households. Of those, $20 \%$ requested materials (City of Portland Office of Transportation 2006). In 2007, 18\% of the 23,400 
households in the Southeast target area ordered materials (Portland Office of Transportation 2007). In 2008, the target area was in Southwest Portland and included 21,500 households, $16 \%$ of which ordered materials (City of Portland Office of Transportation 2006).

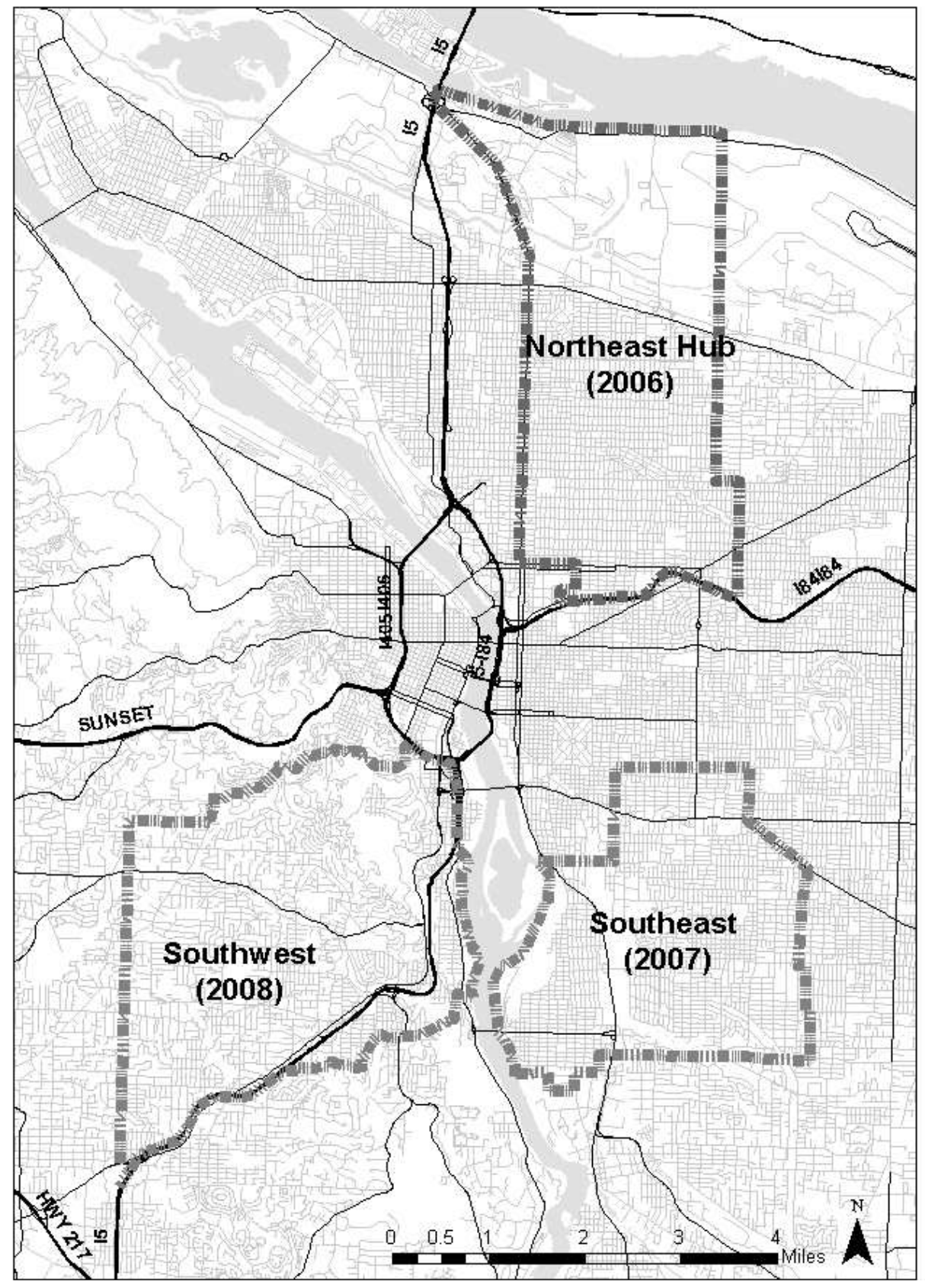

Figure 2 Map of City of Portland SmartTrips Target Areas, 2006-2008 


\subsection{DATA COLLECTION}

\subsubsection{Overview}

As part of the SmartTrips program, the City of Portland contracted with a private firm to conduct random phone surveys before and after program implementation. The surveys asked respondents about all trips made the previous day. For each trip (one-way), the respondent was asked about the trip's purpose (e.g., going to work, going shopping, etc) and mode (e.g., driving alone, transit, walking, etc.). The surveys included a limited number of demographic information and attitude questions.

For the Northeast target area, the City's pre-survey was conducted in March 2006 and the postsurvey in the fall of 2006, immediately after the program's conclusion (Table 3). Our additional post-survey was conducted in fall 2008, two years after the SmartTrips intervention. For the Southeast target area, a pre- and post-survey were conducted by the City in the fall. In addition, the City conducted a survey of Southeast target area residents in March 2006 to use as a control group to compare to the Northeast target area. Our post-survey was conducted in fall 2008, one year after the intervention.

The samples for each of the City's pre- and post-surveys were different. Survey researchers refer to this as a repeated cross-sectional design. This is in contrast to a panel survey, where the same sample of people is surveyed before and after an intervention. A repeated cross-sectional method is generally easier to implement than a panel survey. With a panel, it is usually impossible to recontact every person from the first survey. This attrition requires starting with a larger sample.

However, there are several advantages to using a panel survey design when evaluating the effects of an intervention such as SmartTrips. In particular, a panel can provide more insight into the dynamics of behavior change (Stopher et al. 2006). Moreover, a panel is essential when applying the TPB to behavior change. Therefore, we decided to use a panel design for evaluating the 2008 Southwest SmartTrips intervention. However, funding for this research project began October 1, 2007. The City had already conducted its pre-survey for the Southwest target area in September 2007.

To satisfy this project's research objectives, we conducted an additional pre-survey in spring 2008. That survey included two samples. The first sample included respondents from the City's pre-survey conducted a few months earlier. These respondents were asked the TPB questions (described below) and some additional travel behavior and demographic questions. Of the 420 people that completed the City's pre-survey, 240 completed the additional PSU survey. Because of expected attrition for the panel, we sampled an additional 272 random households. That survey included the same questions from the City's pre-survey, in addition to the TPB and other questions added for this research. We conducted the post-survey in fall 2008, sampling the 512 people who completed the PSU surveys in the spring. Of those, 288 completed the post-survey. 
Table 3 Pre- and Post-Survey Dates

\begin{tabular}{|c|c|c|c|}
\hline Target Area & Pre-survey & Post-survey & Additional post-survey \\
\hline $\begin{array}{l}\text { Northeast } \\
(2006)\end{array}$ & $\begin{array}{l}\text { City of Portland } \\
\text { March 10-24, } 2006 \\
\mathrm{n}=300\end{array}$ & $\begin{array}{l}\text { City of Portland } \\
\text { September 21-October } 4 \text {, } \\
2006 \\
\mathrm{n}=300\end{array}$ & $\begin{array}{l}\text { Portland State Univ. } \\
\text { September 9-October 12, } \\
2008 \\
\mathrm{n}=382\end{array}$ \\
\hline $\begin{array}{l}\text { Southeast } \\
(2007)\end{array}$ & $\begin{array}{l}\text { City of Portland } \\
\text { March } 10-24,2006 \\
\mathrm{n}=300 \\
\text { (control for Northeast) } \\
\text { City of Portland } \\
\text { September } 2006 \\
\mathrm{n}=600\end{array}$ & $\begin{array}{l}\text { City of Portland } \\
\text { September } 2007 \\
n=600\end{array}$ & $\begin{array}{l}\text { Portland State Univ. } \\
\text { September } 9 \text { - October } 12 \text {, } \\
2008 \\
\mathrm{n}=322\end{array}$ \\
\hline \multirow[t]{2}{*}{$\begin{array}{l}\text { Southwest } \\
(2008)\end{array}$} & $\begin{array}{l}\text { City of Portland } \\
\text { September } 2007 \\
\mathrm{n}=420\end{array}$ & \multirow{2}{*}{$\begin{array}{l}\text { Portland State Univ. } \\
\text { Post-survey (panel): } \\
\text { September 10-November 3, } \\
2008 \\
\mathrm{n}=288\end{array}$} & \\
\hline & $\begin{array}{l}\text { Portland State Univ. } \\
\text { March 18-April 7, } 2008 \\
\mathrm{n}=512 \\
\text { (City sample: } 240 \\
\text { New sample: } 272 \text { ) }\end{array}$ & & \\
\hline
\end{tabular}

\subsubsection{Survey Instruments}

\subsubsection{Travel Behavior Information}

To measure actual travel behavior, all of the surveys asked respondents about every trip they made the previous day. For each trip (one-way), respondents were asked for the trip purpose and mode. This is similar to travel diary surveys that public agencies regularly conduct and use for travel demand modeling and transportation planning. With a large enough sample, such surveys are believed to give a relatively accurate snapshot of daily travel.

The difference between a typical travel diary survey and the SmartTrips surveys is that with a diary survey households are recruited ahead of time and asked to record their trips in a paper diary on the travel day assigned. They then either mail the form back or convey the data over the phone. In addition, travel diary surveys usually include every person in the household (except sometimes children under a certain age), while the SmartTrips surveys only included one adult in each household. The text from the phone survey script for these questions is in the Appendix.

People's travel often varies from day to day. While most people drive each day, many people rarely use some modes of transportation, such as walking or bicycling. Therefore, questions about an individual's travel on the previous day may not accurately represent that person's travel patterns over a longer time period. With a large enough sample, this is not a concern when trying to describe the overall travel patterns of the entire group. A person who regularly bicycles might not on the day surveyed, while another respondent might have bicycled on their survey day - the only day they did so that week. However, because one purpose of this research was to measure change in behavior and link that change to individual's attitudes and beliefs, it was important to 
ask additional questions to capture travel behavior more broadly. Three questions were included to address this need:

In the past month how often have you taken TriMet to get somewhere?

In the past month how often have you walked from your home to destinations nearby, such as shops, restaurants, work, school, or errands? Do not include walking around the neighborhood just for exercise.

In the past month how often have you ridden a bicycle from your home to destinations nearby, such as shops, restaurants, work, school, or errands? Do not include biking around the neighborhood just for exercise.
Never
Less than once a month
One to three times a month
About once per week
More than once a week
Don't Know (not offered, but allowed)
Refused (not offered, but allowed)

Respondents also were asked to estimate how many miles per week they drive.

All of the surveys included the following question about recent changes in driving behavior:

Do you think you are driving alone to places more often, less often, or about the same number of times each month as you were three months ago?

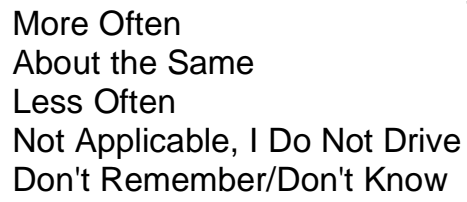

Gas prices rose significantly in the summer of 2008, between the Southwest pre-survey and all three post-surveys. Therefore, two follow-up questions were included on the post-surveys, if the respondent answered "less often" to the question above:

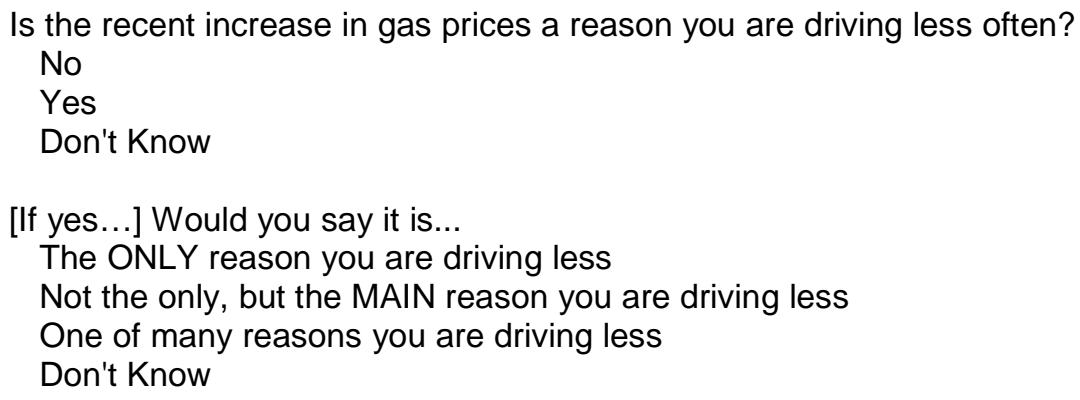

Additional details on gasoline prices at the times of the surveys are presented in the Findings section. 


\subsubsection{Attitudes, Norms, Perceived Behavioral Control, and Intentions}

Large portions of the surveys were devoted to questions aimed at measuring the various components of the TPB model. The questions were chosen and their wording developed based upon surveys used by other researchers to measures attitudes and beliefs related to travel and exercise behavior.

The questions measuring attitudes towards mobility options (transit, walking, bicycling, and driving) were based upon the work of Professors Handy and Mokhtarian at the University of California, Davis. Handy and Mokhtarian have used the questions on at least two large-scale surveys of residents to understand travel mode decisions. The questions are used in a factor analysis, which creates "unobserved" variables (called factors) based upon several of the questions ("observed" variables).

For example, one factor may measure a person's positive attitudes towards transit, using their responses to the questions on transit. Every respondent receives a score for the "pro-transit" factor, with positive and higher scores indicating a stronger positive attitude towards using transit and lower, more negative scores indicating a negative attitude towards transit. Using these factor scores, Mokhtarian and Handy have found a significant relationship between attitudes and travel behavior, sometimes a stronger relationship than with land use (Handy, Cao, and Mokhtarian 2005; Kitamura, Mokhtarian, and Laidet 1997).

One of the investigators on this study (Professor Dill) has used the questions developed by Handy and Mokhtarian on two surveys in the Portland area, one of residents of transit-oriented developments and a random phone survey of adults about bicycling behavior. That work resulted in sets of derived factors very similar to the work of Handy and Mokhtarian, indicating some reliability in the measures. There were, however, some questions that consistently did not contribute to any of the derived factors. To help reduce respondent burden, those questions were eliminated. The final set of attitude questions appears below.

We would also like to ask about your preferences with respect to daily travel. For each, please tell me if you strongly disagree, somewhat disagree, neither agree nor disagree, somewhat agree, or strongly agree.

Walking can sometimes be easier for me than driving.

Travel time is generally wasted time.

I prefer to take transit rather than drive whenever possible.

I like riding a bike.

I use my trip to or from work productively.

I like taking public transit.

Traveling by car is safer overall than walking.

I need a car to do many of the things I like to do.

I prefer to walk rather than drive whenever possible.

I like driving.

I prefer to bike rather than drive whenever possible.

Traveling by car is safer overall than riding a bicycle.

Public transit can sometimes be easier for me than driving.

I try to limit my driving to help improve air quality.

Traveling by car is safer overall than taking public transit.

Getting to work without a car is a hassle.

I like walking. 
Biking can sometimes be easier for me than driving.

The only good thing about traveling is arriving at your destination.

I prefer to organize my errands so that I make as few trips as possible.

The price of gasoline affects the choices I make about my daily travel.

The trip to or from work is a useful transition between home and work.

Fuel efficiency is or would be an important factor for me in choosing a vehicle.

I often use the telephone or the Internet to avoid having to travel somewhere.

When I need to buy something, I usually prefer to get it at the closest store possible.

The region needs to build more highways to reduce traffic congestion.

The questions aimed at measuring norms, perceived behavioral control (PCB), and intentions were developed based upon the work of several researchers applying the TPB to travel mode decisions, bicycle helmet use, and exercise behavior (Bamberg, Ajzen, and Schmidt 2003; Bamberg, Hunecke, and Blobaum 2007; Bamberg, Rölle, and Weber 2003; Coureya and McAuley 1994; Haustein and Hunecke 2007; Lajunen and Rasanen 2004; Norman and Smith 1995; VanRyn, Lytle, and Kirscht 1996).

Three sets of questions were included to measure social norms, using the same agree/disagree scale:

Again, please indicate the extent to which you agree or disagree with each of the following statements.

Most people who are important to me, for example my family and friends, think I should use public transit more.

What about walking more? [Most people who are important to me, (for example my

family and friends), think I should walk more for daily travel.]

What about using a bike more?

What about using your car less?

Most people who are important to me, for example my family and friends, would support me in using public transit more.

What about walking more?

What about using a bike more?

What about using your car less?

Most of my family, friends, and co-workers drive everywhere they need to go.

Many of my family, friends, and co-workers walk to get to places, such as errands, shopping, and work.

Many of my family, friends, and co-workers ride a bike to get to places, such as errands, shopping, and work.

Many of my family, friends, and co-workers use transit regularly.

Using the same response scale, five sets of questions were included to measure perceived behavioral control:

I feel a personal obligation to use public transit instead of the car for everyday travel.

What about walking instead of driving?

What about bicycling instead of driving?

I feel a personal obligation to drive my car less for everyday travel.

For me to use public transit for daily travel from home would be easy.

For me to walk places for daily travel from home would be easy.

For me to ride a bicycle for daily travel from home would be easy.

For me to drive less for daily travel from home would be easy.

I know where safe bike routes are in my neighborhood.

I know where I can walk safely in my neighborhood. 
I know where the buses that stop near my home go to.

I know how often the buses stop near my home.

The buses that stop near my home go to the places I need to get to regularly, such as work, school, or shopping.

Many of the places I need to get to regularly are within walking distance of my home.

Many of the places I need to get to regularly are within biking distance of my home.

I have a bicycle at home that works that I could ride if I wanted to.

I don't have time to use public transit instead of driving.

I don't have time to walk places instead of driving.

I don't have time to bike places instead of driving.

The organization of my everyday life requires a high level of mobility.

The TPB model predicts that behavior is a result of intentions. Therefore, the following questions were included to measure people's intentions to change their travel behavior:

Now I have some questions about your daily travel in the future.

How likely is it that in the next few weeks you will use alternative modes of transportation instead of driving your car for everyday travel. Are you...

Very Unlikely

Somewhat Unlikely

Neither Likely Nor Unlikely

Somewhat Likely

Very Likely

Not Applicable, I Do Not Drive

How likely is it that in the next few weeks you will use TriMet instead of the car for everyday travel. Are you...

How likely is it that in the next few weeks you will walk instead of driving your car for everyday travel.

How likely is it that in the next few weeks you will bike instead of driving your car for everyday travel.

How likely is it that in the next few weeks you will reduce how much you drive your car for everyday travel.

To help determine which stage the respondent might be at for the TTM model, four questions were included (Reed et al., 1997):

Which of these five statements is most reflective of your current walking [bicycling] behavior? We're interested in your walking for daily travel, for example to destinations nearby, such as shops, restaurants, work, school, or errands, rather than walking around the neighborhood just for exercise.

Don't currently walk [ride a bike] and have no intention to in the next 6 months.

Don't currently walk [ride a bike] but intend to within 1 month.

Don't currently walk [ride a bike] but intend to in the next 6 months.

I've regularly walked [ridden a bike] for daily travel for less than 6 months.

I've regularly walked [ridden a bike] for daily travel for more than 6 months.

Which of the five items is most reflective of your current TriMet use?

Don't currently use TriMet and have no intention to begin in the next 6 months.

Don't currently use TriMet but intend to begin within 1 month.

Don't currently use TriMet but intend to begin in the next 6 months.

I've regularly used TriMet for less than 6 months.

I've regularly used TriMet for more than 6 months.

Which of the five items is most reflective of your current driving behavior? IF 
I currently drive and have no intention to reduce it within the next 6 months.

I currently drive but intend to reduce it within 1 month.

I currently drive but intend to reduce it within the next 6 months.

I started to reduce it in the last 6 months.

I have reduced it for more than 6 months.

Not Applicable, I Do Not Drive

\subsubsection{Demographics}

Demographic questions collected data on the following items:

- Number of motor vehicles in the household

- Whether the respondent owned a bicycle

- Total number of people living in the household

- Number of children under 18 living in the household

- Age

- Highest level of education

- Race/ethnicity

- Household income

In addition, respondents were asked to provide the nearest street intersection to their home. This could be used to geo-code respondents' home locations, thus providing additional information about their neighborhood, such as access to transit or bike lanes. Most of the demographic questions were not repeated on the Southwest post-survey, given the short time (about six months) between the pre- and post-surveys.

\subsubsection{Survey Implementation}

The additional Northeast and Southeast post-surveys and the Southwest pre-survey were conducted exclusively on the phone by the Survey Research Laboratory (SRL) at Portland State University. The Northeast and Southeast surveys were drawn from a single sample of phone numbers based upon zip code. Respondents were screened to determine if they lived within a target area and, if so, which one. Targets were set to achieve at least 320 responses from each target area. The response rates for these surveys are shown in Table 4.

Respondents to the PSU Southwest pre-survey were asked if they were willing to participate in a follow-up survey. Those who agreed ( 447 of 508, or $88 \%$ ) were asked if they preferred to do the follow-up survey on the phone or over the Internet. Those who preferred the phone $(n=254$, $57 \%$ ) were contacted for the post-survey by the SRL. Of those, 164 completed the post-survey, representing a $65 \%$ response rate. Those who preferred the Internet or either method $(n=200$, $45 \%$ ) were sent an email inviting them to complete the post-survey online. The Web version of the survey was identical to the phone version. After the initial email invitation, non-respondents were asked via email two additional times to respond. Of those, 124 completed the online survey 
- a $62 \%$ response rate. The overall response rate, based upon the original 512 pre-survey respondents, is $56 \%$.

Table 4 Survey Response Rates

\begin{tabular}{|c|c|c|c|c|c|}
\hline \multirow[b]{2}{*}{ Target area } & \multirow[b]{2}{*}{$\begin{array}{c}\text { Completed } \\
\text { responses }\end{array}$} & \multirow[b]{2}{*}{ Sample size } & \multicolumn{2}{|c|}{$\begin{array}{l}\text { Response Rates } \\
\text { (see notes below) }\end{array}$} & \multirow[b]{2}{*}{$\begin{array}{c}\text { Average call } \\
\text { time }\end{array}$} \\
\hline & & & $\begin{array}{c}\text { Of eligible } \\
\text { numbers }\end{array}$ & $\begin{array}{c}\text { Of } \\
\text { resolved } \\
\text { numbers }\end{array}$ & \\
\hline $\begin{array}{l}\text { Northeast \& } \\
\text { Southeast } \\
\text { September 9- } \\
\text { October 12, } 2008\end{array}$ & 704 & 7,425 & $\begin{array}{c}11 \% \\
(n=6,520)\end{array}$ & $\begin{array}{c}37 \% \\
(n=1,898)\end{array}$ & 20.9 minutes \\
\hline $\begin{array}{l}\text { Southwest: } \\
\text { Re-contact of City } \\
\text { sample } \\
\text { March 18- } \\
\text { April 7, } 2008 \\
\end{array}$ & 236 & 420 & $\begin{array}{c}61 \% \\
(n=394)\end{array}$ & $\begin{array}{c}81 \% \\
(n=298)\end{array}$ & 19.5 minutes \\
\hline $\begin{array}{l}\text { Southwest: } \\
\text { New PSU sample } \\
\text { March 18- } \\
\text { April 7, } 2008 \\
\end{array}$ & 272 & 2,940 & $\begin{array}{c}10 \% \\
(n=2,627)\end{array}$ & $\begin{array}{c}41 \% \\
(n=660)\end{array}$ & 22.9 minutes \\
\hline $\begin{array}{l}\text { Southwest: Post- } \\
\text { Survey (panel) } \\
\text { September 10- } \\
\text { November 3, } 2008\end{array}$ & $\begin{array}{c}288 \\
\text { (phone }=164 \\
\text { web }=124)\end{array}$ & 508 & $57 \%$ & $64 \%$ & $\begin{array}{l}19.8 \text { minutes } \\
\text { (phone only) }\end{array}$ \\
\hline
\end{tabular}

Notes: For all except the Southwest Post-Survey, the following definitions apply:

Resolved numbers are the phone numbers from the original sample that were determined to be eligible or ineligible for the survey. Ineligible numbers include fax machines, non-working numbers, non-residential numbers, pay phones, phones at group homes, households without anyone over 18, households outside the target area, and households with people who were not in Portland the previous day. Eligible households include households that completed the survey, households who refused and said not to call back, households that suspended the survey part way through, and households with a language barrier.

Eligible numbers includes all of the phone numbers from the original sample, minus those determined to be ineligible (see above). The count of eligible numbers includes numbers that were phoned multiple times, but for which eligibility could not be determined because no one answered, the person said to call back but did not answer when called back, or refused to complete the survey but did not say not to call back.

For the Southwest Post-Survey, eligible numbers is the total number of valid respondents from the Pre-Survey (508) and resolved numbers is the total number of Pre-Survey respondents who agreed to do the post-survey (447). 


\subsection{FINDINGS}

\subsection{THE RESPONDENTS}

The demographics of the respondents are shown in Table 5. There are some small differences between the full sample of respondents to the Southwest pre-survey and those who responded to the post-survey and, therefore, were part of the panel. Only one of the differences is statistically significant. The share of respondents in single-person households is lower for the panel $-15 \%$ versus $21 \%$ for the full pre-survey sample. Only a few of the demographic questions were asked on both the pre- and post-surveys in Southwest and there were no significant changes.

There are some notable differences between the respondents in the Southwest, Northeast, and Southeast target areas. Households in Northeast and Southeast had significantly fewer vehicles per adult in their homes - one or fewer - compared to more than 1.1 per adult in the Southwest households. The respondents in Southeast were more likely to be in the youngest and oldest age groups, with fewer middle-aged respondents. They were also more likely to only have a high school degree (or less) and less likely to have a graduate degree. This is probably related to the difference in age structure. Consistent with this, a significantly higher share of the Southeast respondents was in the lowest income category and a lower share in the highest income category, compared to both the Southwest and Northeast respondents. 
Table 5: Respondent Demographics

\begin{tabular}{|c|c|c|c|c|c|}
\hline & \multicolumn{3}{|c|}{ Southwest } & \multirow[b]{2}{*}{ Northeast } & \multirow[b]{2}{*}{ Southeast } \\
\hline & $\begin{array}{l}\text { Pre-survey: } \\
\text { Full sample }\end{array}$ & $\begin{array}{l}\text { Pre-survey: } \\
\text { Panel }\end{array}$ & $\begin{array}{c}\text { Post- } \\
\text { survey: } \\
\text { Panel }\end{array}$ & & \\
\hline \multicolumn{6}{|l|}{ Number of vehicles in household } \\
\hline None & $4 \%$ & $2 \%$ & $2 \%$ & $3 \%$ & $5 \%$ \\
\hline 1 & $28 \%$ & $24 \%$ & $24 \%$ & $34 \%$ & $43 \%$ \\
\hline 2 & $47 \%$ & $51 \%$ & $51 \%$ & $51 \%$ & $35 \%$ \\
\hline 3 or more & $21 \%$ & $23 \%$ & $23 \%$ & $12 \%$ & $17 \%$ \\
\hline $\begin{array}{l}\text { Mean number of vehicles per } \\
\text { adult (std. dev.) }\end{array}$ & $\begin{array}{c}1.1 \\
(0.6)\end{array}$ & $\begin{array}{c}1.1 \\
(0.6)\end{array}$ & $\begin{array}{c}1.1 \\
(0.6)\end{array}$ & $\begin{array}{c}0.9 \\
(0.4)\end{array}$ & $\begin{array}{c}1.0 \\
(0.6)\end{array}$ \\
\hline Own a bicycle & $60 \%$ & $63 \%$ & n.a. & $73 \%$ & $62 \%$ \\
\hline \multicolumn{6}{|l|}{ Age group } \\
\hline $18-34$ & $5 \%$ & $3 \%$ & \multirow{5}{*}{ n.a. } & $7 \%$ & $12 \%$ \\
\hline $35-44$ & $11 \%$ & $12 \%$ & & $14 \%$ & $13 \%$ \\
\hline $45-54$ & $25 \%$ & $29 \%$ & & $23 \%$ & $17 \%$ \\
\hline $55-64$ & $29 \%$ & $30 \%$ & & $30 \%$ & $23 \%$ \\
\hline $65+$ & $30 \%$ & $26 \%$ & & $24 \%$ & $34 \%$ \\
\hline \multicolumn{6}{|l|}{ Education level } \\
\hline $\begin{array}{l}\text { High school graduate or } \\
\text { less }\end{array}$ & $5 \%$ & $4 \%$ & \multirow{5}{*}{ n.a. } & $5 \%$ & $18 \%$ \\
\hline Some college & $21 \%$ & $18 \%$ & & $20 \%$ & $29 \%$ \\
\hline College graduate & $32 \%$ & $31 \%$ & & $32 \%$ & $28 \%$ \\
\hline Some post-graduate & $8 \%$ & $10 \%$ & & $7 \%$ & $7 \%$ \\
\hline Graduate degree & $33 \%$ & $37 \%$ & & $37 \%$ & $18 \%$ \\
\hline Race/ethnicity: White & $94 \%$ & $96 \%$ & n.a. & $87 \%$ & $93 \%$ \\
\hline \multicolumn{6}{|l|}{ Number of people in household } \\
\hline 1 & $21 \%$ & $15 \%$ & $17 \%$ & $19 \%$ & $26 \%$ \\
\hline 2 & $48 \%$ & $53 \%$ & $50 \%$ & $36 \%$ & $39 \%$ \\
\hline 3 or more & $31 \%$ & $31 \%$ & $32 \%$ & $45 \%$ & $30 \%$ \\
\hline Child under 18 in household & $25 \%$ & $26 \%$ & $26 \%$ & $33 \%$ & $32 \%$ \\
\hline \multicolumn{6}{|l|}{ Household income } \\
\hline Less than $\$ 35,000$ & $14 \%$ & $10 \%$ & \multirow{6}{*}{ n.a. } & $14 \%$ & $28 \%$ \\
\hline$\$ 35,000-\$ 49,999$ & $10 \%$ & $11 \%$ & & $12 \%$ & $17 \%$ \\
\hline$\$ 50,000-\$ 74,999$ & $15 \%$ & $15 \%$ & & $17 \%$ & $16 \%$ \\
\hline$\$ 75,000-\$ 99,999$ & $16 \%$ & $18 \%$ & & $17 \%$ & $10 \%$ \\
\hline$\$ 100,000-\$ 149,999$ & $17 \%$ & $20 \%$ & & $20 \%$ & $13 \%$ \\
\hline$\$ 150,000$ or more & $13 \%$ & $13 \%$ & & $13 \%$ & $7 \%$ \\
\hline $\mathrm{N}$ & 512 & 288 & 288 & 382 & 322 \\
\hline
\end{tabular}

n.a. $=$ Not asked. These questions were not asked again on the post-survey

Percentages may not total $100 \%$ due to missing data. 


\subsection{CHANGES IN TRAVEL BEHAVIOR}

\subsubsection{Mode Share for Daily Trips}

\subsubsection{Southwest}

Survey respondents were asked about every trip they made the previous day, referred to here as "daily trips." For the Southwest target area, there were very few differences in the mode share for these daily trips between the pre- and post-surveys. This is particularly true when looking at just the panel of 288 people with both pre- and post-survey data. In the pre-survey, respondents made about half of their reported daily trips driving alone in a private vehicle (Table 6). There is a small and insignificant difference between the full sample (52.0\%) and the panel (50.6\%). In the post-survey, $47.3 \%$ of the trips were made in private vehicles. This is significantly lower $(\mathrm{p}<0.05)$ than the pre-survey full sample, but not the panel. For weekday trips only, the difference is significant for the panel (Table 7), where 55.4\% of the pre-survey trips were made driving alone, compared to $50.2 \%$ of the post-survey trips.

The differences appear to be explained mainly by an increase in walking. A significantly larger share of the daily trips in the post-survey were made by foot (11.0\%), compared to the full presurvey sample (7.6\%). This difference persists when looking at just weekday trips, but not weekend trips (Table 8). There were no statistically significant differences in walking shares within the panel, though the shares were higher in the post-survey for both weekdays and weekends. Rates of carpooling, transit use, and bicycling were about the same in all three samples, for all daily trips, weekday trips, and weekend trips.

Table 6: Mode Share for All Trips, Southwest

\begin{tabular}{|l|c|c|c|}
\hline \multirow{2}{*}{ Travel Mode } & \multicolumn{3}{|c|}{ Percent of trips: All Days } \\
\cline { 2 - 4 } & $\begin{array}{c}\text { Pre-survey: } \\
\text { Full sample }\end{array}$ & $\begin{array}{c}\text { Pre-survey: } \\
\text { Panel }\end{array}$ & $\begin{array}{c}\text { Post-survey: } \\
\text { Panel }\end{array}$ \\
\hline $\begin{array}{l}\text { Drive alone } \\
\text { (includes motorcycle, scooter) }\end{array}$ & $\mathbf{5 2 . 0 \%}$ & $50.6 \%$ & $47.3 \%$ \\
\hline Carpool & $33.4 \%$ & $34.1 \%$ & $35.9 \%$ \\
\hline Transit & $4.4 \%$ & $3.9 \%$ & $4.0 \%$ \\
\hline Bicycle & $2.3 \%$ & $1.9 \%$ & $1.5 \%$ \\
\hline Walk & $\mathbf{7 . 6 \%}$ & $8.9 \%$ & $11.0 \%$ \\
\hline Other & $0.3 \%$ & $0.6 \%$ & $0.2 \%$ \\
\hline N (trips) & 2,506 & 1,077 & 982 \\
\hline N (people) & 687 & 288 & 288 \\
\hline
\end{tabular}

Bold indicates a significant difference from the Post-survey percentage, $p<0.05$ 
Table 7: Mode Share for Weekday Trips, Southwest

\begin{tabular}{|l|c|c|c|}
\hline \multirow{2}{*}{ Travel Mode } & \multicolumn{3}{|c|}{ Percent of trips: Weekdays } \\
\cline { 2 - 4 } & $\begin{array}{c}\text { Pre-survey: } \\
\text { Full sample }\end{array}$ & $\begin{array}{c}\text { Pre-survey: } \\
\text { Panel }\end{array}$ & $\begin{array}{c}\text { Post-survey: } \\
\text { Panel }\end{array}$ \\
\hline $\begin{array}{l}\text { Drive alone } \\
\text { (includes motorcycle, scooter) }\end{array}$ & $\mathbf{5 4 . 9 \%}$ & $\mathbf{5 5 . 4 \%}$ & $50.2 \%$ \\
\hline Carpool & $29.7 \%$ & $28.7 \%$ & $32.3 \%$ \\
\hline Transit & $4.5 \%$ & $4.6 \%$ & $4.5 \%$ \\
\hline Bicycle & $2.5 \%$ & $1.5 \%$ & $1.6 \%$ \\
\hline Walk & $\mathbf{8 . 3 \%}$ & $9.5 \%$ & $11.3 \%$ \\
\hline Other & $0.2 \%$ & $0.2 \%$ & $0.1 \%$ \\
\hline $\mathrm{n}$ (trips) & 1,905 & 841 & 761 \\
\hline $\mathrm{n}$ (people) & 493 & 225 & 223 \\
\hline
\end{tabular}

Bold indicates a significant difference from the Post-survey percentage.

Table 8: Mode Share for Weekend Trips, Southwest

\begin{tabular}{|l|c|c|c|}
\hline \multirow{2}{*}{ Travel Mode } & \multicolumn{3}{|c|}{ Percent of trips: Weekends } \\
\cline { 2 - 4 } & $\begin{array}{c}\text { Pre-survey: } \\
\text { Full sample }\end{array}$ & $\begin{array}{c}\text { Pre-survey: } \\
\text { Panel }\end{array}$ & $\begin{array}{c}\text { Post-survey: } \\
\text { Panel }\end{array}$ \\
\hline $\begin{array}{l}\text { Drive alone } \\
\text { (includes motorcycle, scooter) }\end{array}$ & $38.8 \%$ & $33.5 \%$ & $37.6 \%$ \\
\hline Carpool & $49.3 \%$ & $53.4 \%$ & $48.4 \%$ \\
\hline Transit & $3.4 \%$ & $1.3 \%$ & $2.3 \%$ \\
\hline Bicycle & $2.0 \%$ & $3.4 \%$ & $1.4 \%$ \\
\hline Walk & $\mathbf{5 . 7 \%}$ & $6.8 \%$ & $10.0 \%$ \\
\hline Other & $0.8 \%$ & $1.7 \%$ & $0.5 \%$ \\
\hline $\mathrm{n}$ (trips) & 505 & 236 & 221 \\
\hline $\mathrm{n}$ (people) & 162 & 63 & 65 \\
\hline
\end{tabular}

Bold indicates a significant difference from the Post-survey percentage.

\subsubsection{Northeast and Southeast}

In the Northeast target area, the share of trips made driving alone dropped significantly between the pre- and post-surveys conducted in 2006 by the City, from $64.4 \%$ to $47.3 \%$ (Table 9). The post-survey conducted for this study in 2008 found a comparable share of drive-alone trips 42.8\%. The share of trips made on foot is also comparable between the 2006 and 2008 postsurveys $-14.0 \%$ and $15.8 \%$, respectively. The share of trips made in carpools is significantly higher, while the share made on transit and bicycling is lower. These differences are difficult to explain, particularly the difference in carpool trips, which is very large. While this study attempted to replicate the methodology used by the City, it is possible that the Portland State Survey Research Lab (SRL) staff asked the questions slightly differently or probed more or less than the staff at the survey firm used by the City of Portland, thus eliciting different responses. In addition, many carpool trips are with family or other household members. There may be differences in household size between the two samples. Without the original data from the City's surveys, the differences are difficult to explain. 
Table 9: Mode Share for All Trips - Northeast Target Area

\begin{tabular}{|l|c|c|c|}
\hline \multirow{2}{*}{ Travel Mode } & \multicolumn{3}{|c|}{ Percent of trips: All Days } \\
\cline { 2 - 4 } & \multicolumn{2}{|c|}{ City Surveys } & PSU Survey \\
\cline { 2 - 4 } & $\begin{array}{c}\text { Pre-survey } \\
\text { March 2006 }\end{array}$ & $\begin{array}{c}\text { Post-survey: } \\
\text { Sept/Oct 2006 }\end{array}$ & $\begin{array}{c}\text { Post-survey: } \\
\text { Sept/Oct 2008 }\end{array}$ \\
\hline $\begin{array}{l}\text { Drive alone (includes motorcycle, } \\
\text { scooter, and other) }\end{array}$ & $64.4 \%$ & $47.3 \%$ & $42.8 \%$ \\
\hline Carpool & 18.9 & 21.6 & 31.2 \\
\hline Transit & 6.1 & 7.2 & 2.6 \\
\hline Bicycle & 3.9 & 9.9 & 7.5 \\
\hline Walk & 6.7 & 14.0 & 15.8 \\
\hline $\mathrm{n}$ (trips) & & & 1,591 \\
\hline $\mathrm{n}$ (people) & 300 & 300 & 384 \\
\hline
\end{tabular}

In the Southeast target area, the share of trips made driving alone was significantly lower in the first post-survey (conducted by the City) compared to the combined results from the two presurveys $-51.9 \%$ versus $56.1 \%$ (Table 10 ). The post-survey conducted for this survey one year later found that $45.8 \%$ of the trips were made driving alone, an even lower rate. The shares of trips made by carpool, transit, and bicycling are comparable between the two post-surveys. The share of trips made by foot increased significantly between the two post-surveys, from $8.0 \%$ to $12.0 \%$. The average number of trips per person was significantly higher for the PSU post-survey -3.9 trips per person. This could reflect differences in how the question was asked.

Table 10: Mode Share for All Trips - Southeast Target Area

\begin{tabular}{|c|c|c|c|c|c|}
\hline \multirow[b]{3}{*}{ Travel Mode } & \multicolumn{5}{|c|}{ Percent of trips: All Days } \\
\hline & \multicolumn{4}{|c|}{ City Surveys } & \multirow{2}{*}{$\begin{array}{c}\text { PSU Survey } \\
\text { Post-survey: } \\
\text { Sept./Oct. } 2008\end{array}$} \\
\hline & $\begin{array}{l}\text { Pre-survey } \\
\text { March } 2006\end{array}$ & $\begin{array}{l}\text { Pre-survey } \\
\text { Sept. } 2006 \\
\end{array}$ & $\begin{array}{c}\text { Pre-surveys } \\
\text { combined }\end{array}$ & $\begin{array}{l}\text { Post-survey: } \\
\text { Sept. 2007 }\end{array}$ & \\
\hline $\begin{array}{l}\text { Drive alone } \\
\text { (includes } \\
\text { motorcycle, } \\
\text { scooter, and } \\
\text { other) }\end{array}$ & $60.5 \%$ & $53.7 \%$ & $56.1 \%$ & $51.9 \%$ & $45.8 \%$ \\
\hline Carpool & $23.3 \%$ & $23.3 \%$ & $23.3 \%$ & $29.6 \%$ & $31.4 \%$ \\
\hline Transit & $6.8 \%$ & $6.6 \%$ & $6.7 \%$ & $5.8 \%$ & $5.6 \%$ \\
\hline Bicycle & $2.3 \%$ & $6.8 \%$ & $5.2 \%$ & $4.8 \%$ & $5.2 \%$ \\
\hline Walk & $\mathbf{7 . 0 \%}$ & $9.6 \%$ & $8.7 \%$ & $8.0 \%$ & $12.0 \%$ \\
\hline $\mathrm{n}$ (trips) & 994 & 1,860 & 2,854 & 1,966 & 1,251 \\
\hline $\mathrm{n}$ (people) & 300 & 600 & 900 & 600 & 320 \\
\hline $\begin{array}{l}\text { Mean number of } \\
\text { trips per person }\end{array}$ & 3.3 & 3.1 & 3.2 & 3.3 & 3.9 \\
\hline
\end{tabular}

Bold indicates a significant difference from the PSU post-survey percentage, $\mathrm{p}<0.05$, 2-tailed test. 


\subsubsection{Use of Other Modes in the Previous Month}

As another gauge of travel behavior, the surveys asked about frequency of using transit, walking, and bicycling within the past month. Because this question was only asked on the PSU surveys, it is only possible to measure change over time for the Southwest target area.

In the Southwest target area, there was no statistically significant shift in the frequency of TriMet use (Table 11) or walking from home to destinations in the previous month (Table 12). There was, however, a statistically significant shift in the frequency of bicycling from home to destinations in the previous month (Table 13). A larger share of respondents stated that they had ridden more than once a week, and a smaller share stated that they have never biked or biked less than once a month.

This finding contrasts with the trip diary data, which revealed no differences in the share of bicycling trips. This may reflect the fact that the baseline bicycling rates are low in this neighborhood, and a one-day trip diary may miss some bicycling behavior. The difference may also be due, at least in part, to the timing of the two surveys. For the pre-survey, the question was asked in late March and early April. The post-survey was conducted in late September and early October. Therefore, the "previous month" for the post-survey may have better weather than the pre-survey. However, this explanation does not seem to have caused a shift in walking behavior in the past month.

Table 11: Use of TriMet in the Past Month, Southwest

\begin{tabular}{|l|c|c|c|}
\hline \multirow{2}{*}{$\begin{array}{l}\text { In the past month, how often have } \\
\text { you taken TriMet to get somewhere? }\end{array}$} & $\begin{array}{c}\text { Pre-survey: } \\
\text { Full sample }\end{array}$ & $\begin{array}{c}\text { Pre-survey: } \\
\text { Panel }\end{array}$ & $\begin{array}{c}\text { Post-survey: } \\
\text { Panel }\end{array}$ \\
\cline { 2 - 4 } Never & $51.4 \%$ & $50.0 \%$ & $51.0 \%$ \\
\hline Less than once a month & $9.2 \%$ & $8.7 \%$ & $11.1 \%$ \\
\hline $1-3$ times a month & $18.9 \%$ & $19.8 \%$ & $19.4 \%$ \\
\hline About once per week & $6.8 \%$ & $6.9 \%$ & $5.6 \%$ \\
\hline More than once a week & $13.7 \%$ & $14.6 \%$ & $12.8 \%$ \\
\hline N (people) & 512 & 288 & 288 \\
\hline
\end{tabular}

There are no significant differences between the Pre-survey and Post-survey percentages, $\mathrm{p}<0.05$.

Table 12: Walking from Home in the Past Month, Southwest

\begin{tabular}{|l|c|c|c|}
\hline \multirow{2}{*}{$\begin{array}{l}\text { In the past month, how often have } \\
\text { you } \text { walked from you home to } \\
\text { destinations nearby, such as shops...? }\end{array}$} & $\begin{array}{c}\text { Pre-survey: } \\
\text { Full sample }\end{array}$ & $\begin{array}{c}\text { Pre-survey: } \\
\text { Panel }\end{array}$ & $\begin{array}{c}\text { Post-survey: } \\
\text { Panel }\end{array}$ \\
\cline { 2 - 4 } Never & $37.5 \%$ & $36.1 \%$ & $35.1 \%$ \\
\hline Less than once a month & $6.3 \%$ & $6.9 \%$ & $7.3 \%$ \\
\hline $1-3$ times a month & $17.6 \%$ & $16.3 \%$ & $17.4 \%$ \\
\hline About once per week & $15.8 \%$ & $16.3 \%$ & $18.1 \%$ \\
\hline More than once a week & $22.9 \%$ & $24.3 \%$ & $22.2 \%$ \\
\hline $\mathrm{n}$ (people) & 512 & 288 & 288 \\
\hline
\end{tabular}

There are no significant differences between the Pre-survey and Post-survey percentages, $\mathrm{p}<0.05$. 
Table 13: Biking from Home in the Past Month, Southwest

\begin{tabular}{|l|c|c|c|}
\hline \multirow{2}{*}{$\begin{array}{l}\text { In the past month, how often have } \\
\text { you ridden a bicycle from you home } \\
\text { to destinations nearby, such as } \\
\text { shops...? }\end{array}$} & $\begin{array}{l}|c| \\
\text { Pre-survey: } \\
\text { Full sample }\end{array}$ & $\begin{array}{c}\text { Pre-survey: } \\
\text { Panel }\end{array}$ & $\begin{array}{c}\text { Post-survey: } \\
\text { Panel }\end{array}$ \\
\hline Never & $\mathbf{8 2 . 6 \%}$ & $\mathbf{7 9 . 9 \%}$ & $70.1 \%$ \\
\hline Less than once a month & $\mathbf{2 . 5 \%}$ & $\mathbf{3 . 1 \%}$ & $8.0 \%$ \\
\hline $1-3$ times a month & $6.3 \%$ & $8.0 \%$ & $8.7 \%$ \\
\hline About once per week & $3.1 \%$ & $3.1 \%$ & $3.1 \%$ \\
\hline More than once a week & $\mathbf{5 . 3 \%}$ & $\mathbf{5 . 9 \%}$ & $9.7 \%$ \\
\hline n (people) & 512 & 288 & 288 \\
\hline
\end{tabular}

Bold indicates a significant difference from the Post-survey percentage, $\mathrm{p}<0.05$.

\subsubsection{Number of Trips and Gas Prices}

Overall, Southwest target area respondents made significantly fewer trips (all modes) in the postsurvey, compared to the pre-survey (Table 15). Some of this may be due to the gas price increases that occurred in the summer of 2008. The gas prices at the time of all of the surveys are shown in Table 14 and for Southwest only in Figure 3. Gas prices peaked about two months before the post-survey.

Table 14 Gas Prices During Pre- and Post-Survey Dates

\begin{tabular}{|c|c|c|c|}
\hline Target Area & Pre-survey & Post-survey & Additional post-survey \\
\hline $\begin{array}{l}\text { Northeast } \\
(2006)\end{array}$ & $\begin{array}{l}\text { City of Portland } \\
\text { March } 10-24,2006 \\
\$ \mathbf{2 . 1 2}-\mathbf{\$ 2 . 4 0}\end{array}$ & $\begin{array}{l}\text { City of Portland } \\
\text { September 21-October 4, } 2006 \\
\mathbf{\$ 2 . 5 8} \text { - } \$ \mathbf{2 . 8 1}\end{array}$ & $\begin{array}{l}\text { Portland State Univ. } \\
\text { September 9-October 12, } 2008 \\
\mathbf{\$ 3 . 2 8 - \$ 3 . 6 8}\end{array}$ \\
\hline $\begin{array}{l}\text { Southeast } \\
\text { (2007) }\end{array}$ & $\begin{array}{l}\text { City of Portland } \\
\text { March 10-24, } 2006 \\
\mathbf{\$ 2 . 1 2}-\mathbf{\$ 2 . 4 0} \\
\\
\text { City of Portland } \\
\text { September } 2006 \\
\mathbf{\$ 2 . 5 8}-\mathbf{\$ 2 . 9 2}\end{array}$ & $\begin{array}{l}\text { City of Portland } \\
\text { September } 2007 \\
\mathbf{\$ 2 . 5 8}-\mathbf{\$ 2 . 8 1}\end{array}$ & $\begin{array}{l}\text { Portland State Univ. } \\
\text { September } 9 \text {-October 12, } 2008 \\
\mathbf{\$ 3 . 2 8 - \$ 3 . 6 8}\end{array}$ \\
\hline $\begin{array}{l}\text { Southwest } \\
\text { (2008) }\end{array}$ & $\begin{array}{l}\text { City of Portland } \\
\text { September } 2007 \\
\mathbf{\$ 2 . 5 8}-\mathbf{\$ 2 . 8 1} \\
\text { Portland State Univ. } \\
\text { March 18-April 7, } 2008 \\
\mathbf{\$ 3 . 3 8}-\mathbf{\$ 3 . 4 5} \\
\end{array}$ & $\begin{array}{l}\text { Portland State Univ. } \\
\text { Post-survey (panel): } \\
\text { September 10-November 3, } \\
2008 \\
\mathbf{\$ 2 . 7 8 - \$ 3 . 6 8}\end{array}$ & \\
\hline
\end{tabular}

Source: AAA Oregon, http://www.aaaorid.com/news/gas_trends.asp. Data for Portland region. 


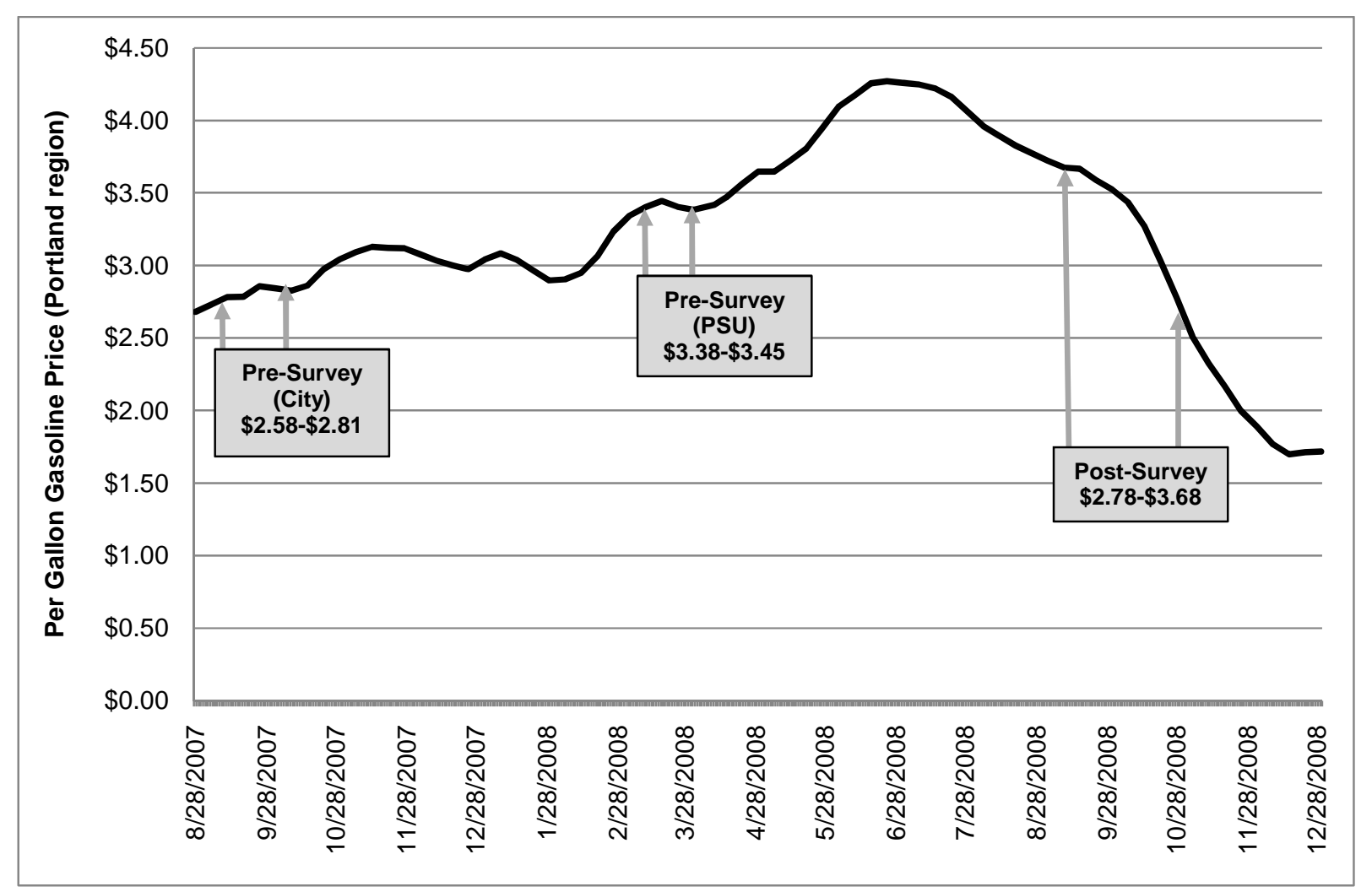

Source: AAA Oregon, http://www.aaaorid.com/news/gas_trends.asp. Data for Portland region.

\section{Figure 3: Portland Gas Price Trends During Study Period}

Overall, $31 \%$ of the post-survey respondents said that they were driving alone less than three months previously (Table 16). Of these, $82 \%$ said that gas prices were at least part of the reason why. However, gas prices were not the main reason for this shift for most $(72.6 \%)$ of these respondents. These numbers are similar to respondents in the Northeast and Southeast neighborhoods (Table 17).

Table 15: Average Number of Trips per Day per Person, Southwest

\begin{tabular}{|c|c|c|c|}
\hline & $\begin{array}{c}\text { Pre-survey: } \\
\text { Full sample }\end{array}$ & $\begin{array}{c}\text { Pre-survey: } \\
\text { Panel }\end{array}$ & $\begin{array}{c}\text { Post-survey: } \\
\text { Panel }\end{array}$ \\
\hline Avg. number of trips per person & 3.7 & 3.7 & 3.4 \\
\hline Weekday & 3.9 & 3.7 & 3.4 \\
\hline Weekend & 3.1 & 3.7 & 3.4 \\
\hline
\end{tabular}


Table 16: Changes in Driving and Role of Gas Prices, Southwest

\begin{tabular}{|c|c|c|}
\hline & $\%$ & $\mathbf{n}$ \\
\hline \multicolumn{3}{|l|}{ Do you think you are driving alone to places...than three months ago } \\
\hline More often & $2.8 \%$ & 8 \\
\hline About the same & $63.5 \%$ & 183 \\
\hline Less often & $30.9 \%$ & 89 \\
\hline Not applicable, I do not drive & $2.8 \%$ & 8 \\
\hline \multicolumn{3}{|c|}{$\begin{array}{l}\text { Of those who are driving less... } \\
\text { Is the recent increase in gas prices a reason you are driving less often? }\end{array}$} \\
\hline Yes & $82 \%$ & 73 \\
\hline \multicolumn{3}{|l|}{ Is it... } \\
\hline The ONLY reason you are driving less & $1.4 \%$ & 1 \\
\hline $\begin{array}{l}\text { Not the only, but the MAIN reason you are driving } \\
\text { less }\end{array}$ & $24.7 \%$ & 18 \\
\hline One of many reasons for driving less & $72.6 \%$ & 53 \\
\hline Do not know & $1.4 \%$ & 1 \\
\hline
\end{tabular}

Table 17: Changes in Driving and Role of Gas Prices, Northeast and Southeast

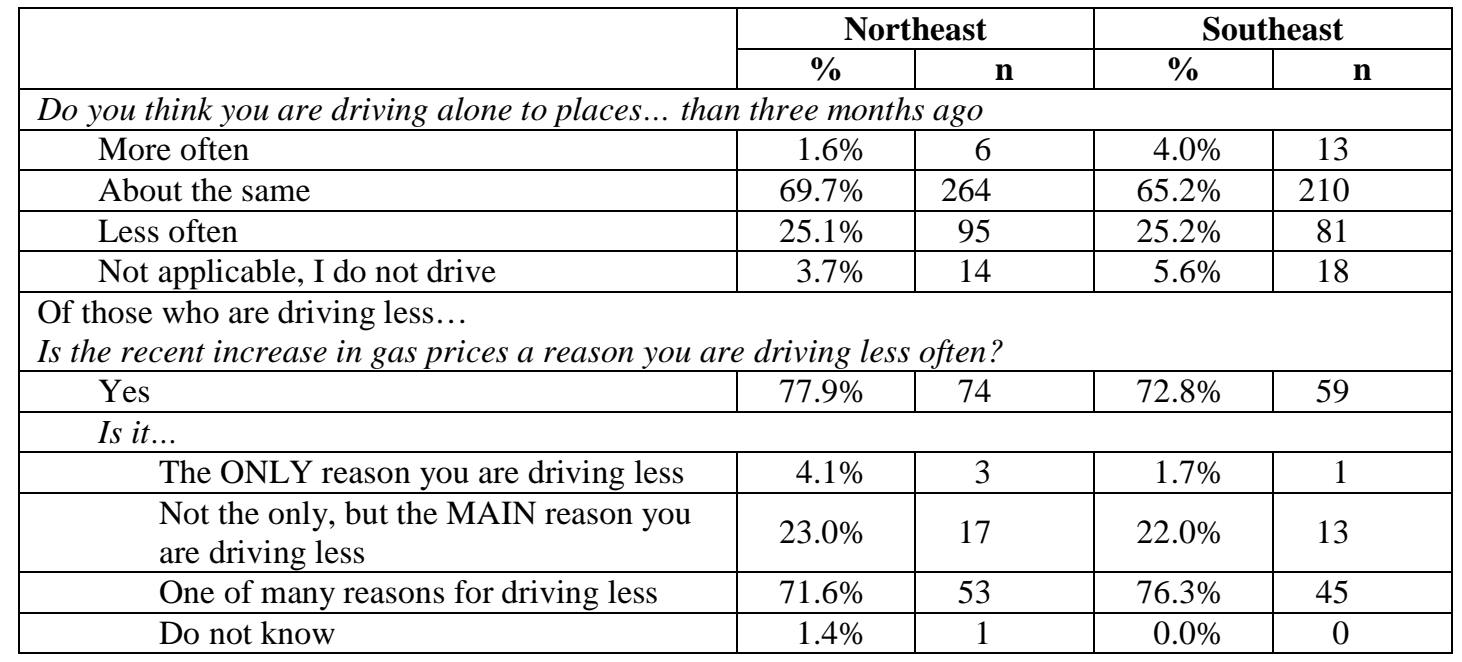

\subsubsection{Participation in SmartTrips}

In the Southwest post-survey, $61 \%$ of the 288 respondents $(n=175)$ remembered receiving the SmartTrips order form in the mail. Of these, $30 \%$ ordered materials. This represents $18 \%$ of the entire post-survey sample. Only $3 \%$ of the 288 respondents participated in a SmartTrips event, such as Summer Cycle, Ten Toe Express, and Senior Strolls.

There are some differences in the respondents who were more likely to order materials and their travel behavior in the pre-survey. Those who had walked from their home to a nearby destination at least once in the past month (pre-survey) were more likely to order materials (Table 18). Those who had used TriMet or biked were also more likely to order materials, but those 
differences were not statistically significant. These findings indicate that the SmartTrips program materials may be more appealing to people who were already using alternative modes more often. There were no significant differences in the average number of daily trips made by bike, foot, TriMet, or carpool (pre-survey) between those who ordered materials and those who did not.

Table 18: Differences between in Ordering SmartTrips Materials by Pre-Survey Travel Behavior, Southwest

\begin{tabular}{|l|c|c|c|}
\hline \multirow{2}{*}{ Pre-survey travel behavior } & \multicolumn{3}{|c|}{$\%$ who did or did not order Smart } \\
\cline { 2 - 4 } & Did not order & Did order & naterials \\
\hline TriMet use in the past month & & & \\
\hline Never or less than once & $83 \%$ & $17 \%$ & 169 \\
\hline Once a month or more & $80 \%$ & $20 \%$ & 119 \\
\hline $\begin{array}{l}\text { Walking from home to a destination in the } \\
\text { past month }\end{array}$ & & & \\
\hline Never or less than once & $\mathbf{8 8 \%}$ & $\mathbf{1 2 \%}$ & 124 \\
\hline Once a month or more & $\mathbf{7 7 \%}$ & $\mathbf{2 3 \%}$ & 164 \\
\hline $\begin{array}{l}\text { Biking from home to a destination in the past } \\
\text { month }\end{array}$ & & & \\
\hline Never or less than once & $83 \%$ & $17 \%$ & 239 \\
\hline Once a month or more & $75 \%$ & $25 \%$ & 49 \\
\hline All Respondents & $82 \%$ & $18 \%$ & 288 \\
\hline
\end{tabular}

Bold indicates a significant difference, $\mathrm{p}<0.05$.

There were differences in travel behavior after the SmartTrips program between people who participated by ordering materials and those who did not. Southwest respondents who ordered materials were significantly more likely to have taken transit or biked from home once a month or more in the past month (Table 19). Northeast residents who ordered materials were significantly more likely to have taken transit in the past month (Table 20). Southeast respondents who ordered materials were significantly more likely to have taken transit or walked in the past month. Looking at the daily trip information, there were fewer significant differences between those who ordered materials and those who did not (Table 21). Southwest residents who ordered materials made more bike trips on the previous day. One issue with interpreting these results is the direction of causality. As shown above, people who ordered materials in Southwest were somewhat more likely to already use alternatives to driving alone. 
Table 19: Differences between Respondents Who Did and Did Not Order SmartTrips Materials and PostSurvey Travel Behavior, Southwest

\begin{tabular}{|l|c|c|}
\hline \multirow{2}{*}{ Post-survey travel behavior } & \multicolumn{2}{|c|}{ Southwest } \\
\cline { 2 - 3 } & $\begin{array}{c}\text { Did not order } \\
\text { materials }\end{array}$ & Did order materials \\
\hline TriMet use in the past month & & $\mathbf{5 0 \%}$ \\
\hline Never or less than once & $\mathbf{6 5 \%}$ & $\mathbf{5 0 \%}$ \\
\hline Once a month or more & $\mathbf{3 5 \%}$ & $35 \%$ \\
\hline Walking from home to a destination in the past month & & $65 \%$ \\
\hline Never or less than once & $44 \%$ & \\
\hline Once a month or more & $56 \%$ & $\mathbf{6 5 \%}$ \\
\hline Biking from home to a destination in the past month & & $\mathbf{3 5 \%}$ \\
\hline$\quad$ Never or less than once & $\mathbf{8 1 \%}$ & 52 \\
\hline$\quad$ Once a month or more & $\mathbf{1 9 \%}$ & 236 \\
\hline $\mathrm{N} \quad$ & & \\
\hline
\end{tabular}

Bold indicates a significant difference, $\mathrm{p}<0.05$.

Table 20: Use of Transit, Walking and Bicycling in the Past Month - Respondents Who Did and Did Not Order SmartTrips Materials, Northeast and Southeast

\begin{tabular}{|l|c|c|c|c|}
\hline \multirow{2}{*}{\begin{tabular}{l} 
Post-survey travel behavior \\
\cline { 2 - 4 }
\end{tabular}} & $\begin{array}{c}\text { Did not } \\
\text { order }\end{array}$ & Did order & $\begin{array}{c}\text { Sid not } \\
\text { order }\end{array}$ & Did order \\
\hline TriMet use in the past month & & & & \\
\hline Never or less than once & $\mathbf{5 4 \%}$ & $\mathbf{3 2 \%}$ & $\mathbf{7 1 \%}$ & $\mathbf{4 7 \%}$ \\
\hline Once a month or more & $\mathbf{4 6 \%}$ & $\mathbf{6 8 \%}$ & $\mathbf{2 9 \%}$ & $\mathbf{5 3 \%}$ \\
\hline $\mathrm{n}$ & 55 & 81 & 45 & 51 \\
\hline $\begin{array}{l}\text { Walking from home to a destination in the past } \\
\text { month }\end{array}$ & & & & \\
\hline Never or less than once & $18 \%$ & $10 \%$ & $\mathbf{3 3 \%}$ & $\mathbf{1 8 \%}$ \\
\hline Once a month or more & $82 \%$ & $90 \%$ & $\mathbf{6 7 \%}$ & $\mathbf{8 2 \%}$ \\
\hline $\mathrm{n}$ & 55 & 81 & 45 & 50 \\
\hline $\begin{array}{l}\text { Biking from home to a destination in the past } \\
\text { month }\end{array}$ & & & & \\
\hline Never or less than once & $64 \%$ & $59 \%$ & $64 \%$ & $56 \%$ \\
\hline $\begin{array}{l}\text { Once a month or more } \\
\text { All Respondents }\end{array}$ & $36 \%$ & $41 \%$ & $36 \%$ & $44 \%$ \\
\hline
\end{tabular}

Note: Only includes people who remembered receiving the order form for materials.

Bold indicates a significant difference between did and did not order, $\mathrm{p}<0.05$, one-tail test. 
Table 21: Trips by Mode - Respondents Who Did and Did Not Order SmartTrips Materials

\begin{tabular}{|c|c|c|c|c|c|c|c|}
\hline & & & $\begin{array}{c}\text { Number } \\
\text { of transit } \\
\text { trips }\end{array}$ & $\begin{array}{c}\text { Number } \\
\text { of drive } \\
\text { alone } \\
\text { trips }\end{array}$ & $\begin{array}{c}\text { Number } \\
\text { of } \\
\text { carpool } \\
\text { trips }\end{array}$ & $\begin{array}{c}\text { Number } \\
\text { of bike } \\
\text { trips }\end{array}$ & $\begin{array}{c}\text { Number } \\
\text { of walk } \\
\text { trips }\end{array}$ \\
\hline \multirow{4}{*}{ Southwest } & \multirow{2}{*}{$\begin{array}{l}\text { Did not } \\
\text { order } \\
(n=236)\end{array}$} & Mean & 0.12 & 1.62 & 1.17 & 0.03 & 0.36 \\
\hline & & Std. dev. & 0.51 & 1.61 & 1.68 & 0.20 & 0.96 \\
\hline & \multirow{2}{*}{$\begin{array}{l}\text { Ordered } \\
\text { materials } \\
(n=52)\end{array}$} & Mean & 0.19 & 1.56 & 1.50 & 0.17 & 0.42 \\
\hline & & Std. dev. & 0.72 & 1.90 & 1.61 & 0.62 & 0.80 \\
\hline \multirow{4}{*}{ Northeast } & \multirow{2}{*}{$\begin{array}{l}\text { Did not } \\
\text { order } \\
(n=55)\end{array}$} & Mean & 0.13 & 1.56 & 1.09 & 0.18 & 0.64 \\
\hline & & Std. dev. & 0.47 & 1.63 & 1.91 & 0.72 & 1.16 \\
\hline & \multirow{2}{*}{$\begin{array}{l}\text { Ordered } \\
\text { materials } \\
(\mathrm{n}=81)\end{array}$} & Mean & 0.16 & 1.74 & 1.35 & 0.36 & 0.85 \\
\hline & & Std. dev. & 0.54 & 1.71 & 2.02 & 0.86 & 1.60 \\
\hline \multirow{4}{*}{ Southeast } & \multirow{2}{*}{$\begin{array}{l}\text { Did not } \\
\text { order } \\
(n=45)\end{array}$} & Mean & 0.22 & 2.27 & 1.13 & 0.27 & 0.51 \\
\hline & & Std. dev. & 0.67 & 1.98 & 1.59 & 0.78 & 1.34 \\
\hline & \multirow{2}{*}{$\begin{array}{l}\text { Ordered } \\
\text { materials } \\
(n=51)\end{array}$} & Mean & 0.14 & 1.75 & 1.24 & 0.29 & 0.76 \\
\hline & & Std. dev. & 0.49 & 1.83 & 1.70 & 0.90 & 1.73 \\
\hline
\end{tabular}

Bold indicates a significant difference between did and did not order, $\mathrm{p}<0.05$, one-tail test.

\subsubsection{Intentions to Use Other Modes}

The findings from the questions about intentions to use transit, walk, bicycle, or reduce driving in the future are shown in Table 22, Table 23, Table 24, and Table 25. The majority of respondents indicated that they were either already regularly using those modes or that they had no intention to do so in the next six months. There were also no significant shifts in intentions between the pre- and post-surveys. These findings may also indicate some weaknesses in capturing intentions with these particular survey questions. 
Table 22: Intentions for Walking for Daily Travel, Southwest

\begin{tabular}{|l|c|c|c|}
\hline \multirow{2}{*}{$\begin{array}{l}\text { Which of the following statements is } \\
\text { most reflective of your current }\end{array}$} & \multicolumn{3}{|c|}{ Percent of respondents } \\
\cline { 2 - 4 } & $\begin{array}{c}\text { Pre-survey: } \\
\text { Full sample }\end{array}$ & $\begin{array}{c}\text { Pre-survey: } \\
\text { Panel }\end{array}$ & Post-survey \\
\hline $\begin{array}{l}\text { Don't currently walk and have no } \\
\text { intention to in the next 6 months }\end{array}$ & $40.0 \%$ & $39.6 \%$ & $36.5 \%$ \\
\hline $\begin{array}{l}\text { Don't currently walk, but intend to } \\
\text { within one month }\end{array}$ & 9.1 & 6.7 & 6.9 \\
\hline $\begin{array}{l}\text { Don't currently walk, but intend to in } \\
\text { the next 6 months }\end{array}$ & 8.0 & 7.7 & 7.9 \\
\hline $\begin{array}{l}\text { I've regularly walked for daily travel } \\
\text { for less than 6 months }\end{array}$ & 6.0 & 5.6 & 7.6 \\
\hline $\begin{array}{l}\text { I've regularly walked for daily travel } \\
\text { for more than 6 months }\end{array}$ & 37.0 & 40.1 & 41.2 \\
\hline n (people) & 503 & 285 & 277 \\
\hline
\end{tabular}

Table 23: Intentions for Bicycling for Daily Travel, Southwest

\begin{tabular}{|l|c|c|c|}
\hline Which of the following statements is & \multicolumn{3}{|c|}{ Percent of respondents } \\
\cline { 2 - 4 } $\begin{array}{l}\text { most reflective of your current } \\
\text { bicycle riding behavior? }\end{array}$ & $\begin{array}{c}\text { Pre-survey: } \\
\text { Full sample }\end{array}$ & $\begin{array}{c}\text { Pre-survey: } \\
\text { Panel }\end{array}$ & Post-survey \\
\hline $\begin{array}{l}\text { Don't currently ride a bike, and have no } \\
\text { intention to in the next 6 months }\end{array}$ & $65.8 \%$ & $64.9 \%$ & $65.9 \%$ \\
\hline $\begin{array}{l}\text { Don't currently ride a bike, but intend } \\
\text { to within one month }\end{array}$ & 9.6 & 9.4 & 4.3 \\
\hline $\begin{array}{l}\text { Don't currently ride a bike, but intend } \\
\text { to in the next 6 months }\end{array}$ & 9.4 & 9.4 & 10.0 \\
\hline $\begin{array}{l}\text { I've regularly ridden a bike for daily } \\
\text { travel for less than 6 months }\end{array}$ & 2.8 & 2.8 & 3.9 \\
\hline $\begin{array}{l}\text { I've regularly ridden a bike for daily } \\
\text { travel for more than 6 months }\end{array}$ & 12.4 & 13.5 & 15.8 \\
\hline $\mathrm{n}$ (people) & 509 & 288 & 279 \\
\hline
\end{tabular}


Table 24: Intentions for Taking Transit for Daily Travel, Southwest

\begin{tabular}{|c|c|c|c|}
\hline \multirow{2}{*}{$\begin{array}{l}\text { Which of the following statements is } \\
\text { most reflective of your current } \\
\text { TriMet use? }\end{array}$} & \multicolumn{3}{|c|}{ Percent of respondents } \\
\hline & $\begin{array}{l}\text { Pre-survey: } \\
\text { Full sample }\end{array}$ & $\begin{array}{l}\text { Pre-survey: } \\
\text { Panel }\end{array}$ & Post-survey \\
\hline $\begin{array}{l}\text { Don't currently use TriMet and have no } \\
\text { intention to in the next } 6 \text { months }\end{array}$ & $49.7 \%$ & $49.8 \%$ & $54.2 \%$ \\
\hline $\begin{array}{l}\text { Don't currently use TriMet, but intend } \\
\text { to within one month }\end{array}$ & 3.9 & 2.1 & 3.3 \\
\hline $\begin{array}{l}\text { Don't currently use TriMet, but intend } \\
\text { to in the next } 6 \text { months }\end{array}$ & 9.3 & 7.7 & 9.2 \\
\hline $\begin{array}{l}\text { I've regularly used TriMet for daily } \\
\text { travel for less than } 6 \text { months }\end{array}$ & 5.3 & 4.2 & 3.3 \\
\hline $\begin{array}{l}\text { I've regularly used TriMet for daily } \\
\text { travel for more than } 6 \text { months }\end{array}$ & 31.8 & 36.1 & 31.9 \\
\hline n (people) & 507 & 285 & 273 \\
\hline
\end{tabular}

Table 25: Intentions for Reducing Driving, Southwest

\begin{tabular}{|c|c|c|c|}
\hline \multirow{2}{*}{$\begin{array}{l}\text { Which of the following statements is } \\
\text { most reflective of your current } \\
\text { driving behavior? }\end{array}$} & \multicolumn{3}{|c|}{ Percent of respondents } \\
\hline & $\begin{array}{l}\text { Pre-survey: } \\
\text { Full sample }\end{array}$ & $\begin{array}{l}\text { Pre-survey: } \\
\text { Panel }\end{array}$ & Post-survey \\
\hline $\begin{array}{l}\text { I currently drive and have no intention } \\
\text { reduce it within the next } 6 \text { months }\end{array}$ & $31.6 \%$ & $29.2 \%$ & $31.3 \%$ \\
\hline $\begin{array}{l}\text { I currently drive, but intend to reduce it } \\
\text { within the next one month }\end{array}$ & 9.1 & 12.5 & 7.7 \\
\hline $\begin{array}{l}\text { I currently drive, but intend to reduce it } \\
\text { within the next } 6 \text { months }\end{array}$ & 6.4 & 8.3 & 7.4 \\
\hline $\begin{array}{l}\text { I started to reduce my driving in the last } \\
6 \text { months }\end{array}$ & 13.4 & 18.4 & 16.9 \\
\hline $\begin{array}{l}\text { I have reduced my driving to more than } \\
6 \text { months }\end{array}$ & 18.9 & 30.6 & 34.5 \\
\hline Not applicable, do not drive & 3.3 & 1.0 & 2.1 \\
\hline n (people) & 509 & 288 & 284 \\
\hline
\end{tabular}

\subsection{THEORY OF PLANNED BEHAVIOR}

\subsubsection{Descriptive Results}

The respondents' attitudes towards four travel modes are shown in Figure 4 and Figure 5. The results for all of the attitude questions are shown in Table 26. With a few exceptions, attitudes among the Southwest panel respondents did not change significantly between the pre- and postsurveys. The exceptions were as follows:

- Walking can sometimes be easier for me than driving: Agreement dropped

- I prefer to take transit rather than drive whenever possible: Agreement dropped

- I like riding a bike: Agreement increased 
- Traveling by car is safer overall than walking: Agreement dropped

- Traveling by car is safer overall than taking public transit: Agreement dropped

Only one of these changes - a more positive attitude towards riding a bike - is consistent with the intent of the SmartTrips program. However, it is not clear if this change is due directly to participation in the SmartTrips program. Attitudes were more positive in the pre-survey among respondents who ordered SmartTrips materials compared to those who did not. However, the level of agreement only significantly increased among those who did not order materials.

The change in attitude about the safety of traveling by car versus public transit may have been influenced by an incident in June 2008, where several teenagers were arrested for attacking a woman on a MAX light-rail train. Press coverage of the incident stated that it "revived worries about mass transit safety since several high-profile incidents last winter" (Rivera, 2008).

There are some notable differences in attitudes between the Southwest, Northeast, and Southeast neighborhoods. For example, respondents in Northeast generally had more positive attitudes towards bicycling. These respondents were also more likely to agree that walking can sometimes be easier than driving. Respondents from both Northeast and Southeast were less likely to agree that they needed a car to do many of the things they like to do and that a car was safer overall than walking. These differences in attitudes likely reflect physical differences in the neighborhoods. The Northeast and Southeast neighborhoods have a grid street pattern with a greater mix of land uses nearby and more bike lanes, bike boulevards, and sidewalks than many parts of the Southwest target area. 


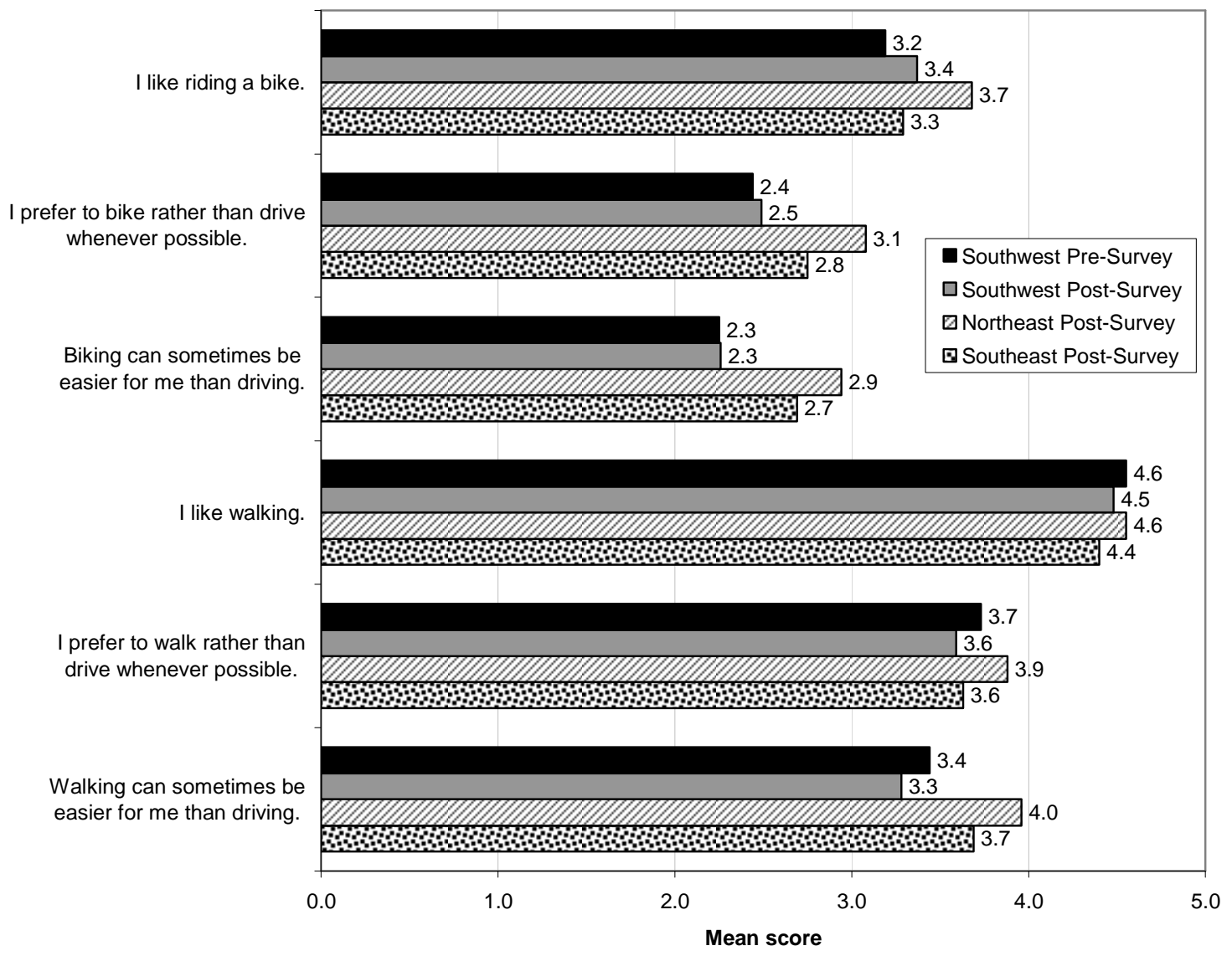

Figure 4 Respondents Attitudes towards Walking and Bicycling 
Traveling by car is safer overall than taking public transit.

Traveling by car is safer overall than riding a bicycle.

Traveling by car is safer overall than walking.

Getting to work without a car is a hassle.

I need a car to do many of the things I like to do.

I like taking public transit.

I prefer to take transit rather than drive whenever possible.

Public transit can sometimes be easier for me than driving.
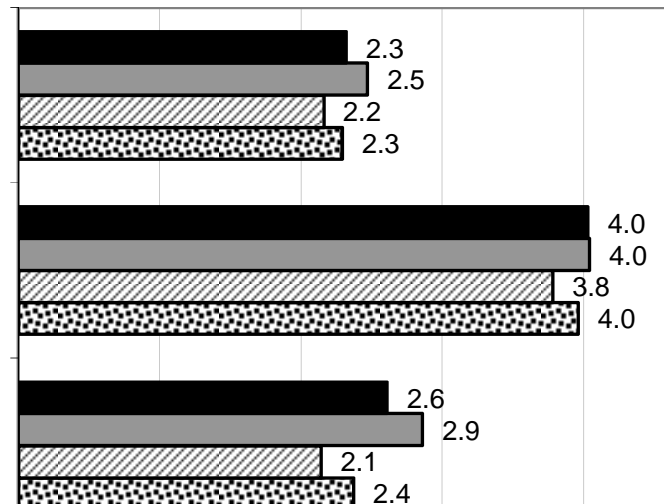

2.9

मेस)से 2.4

I like driving
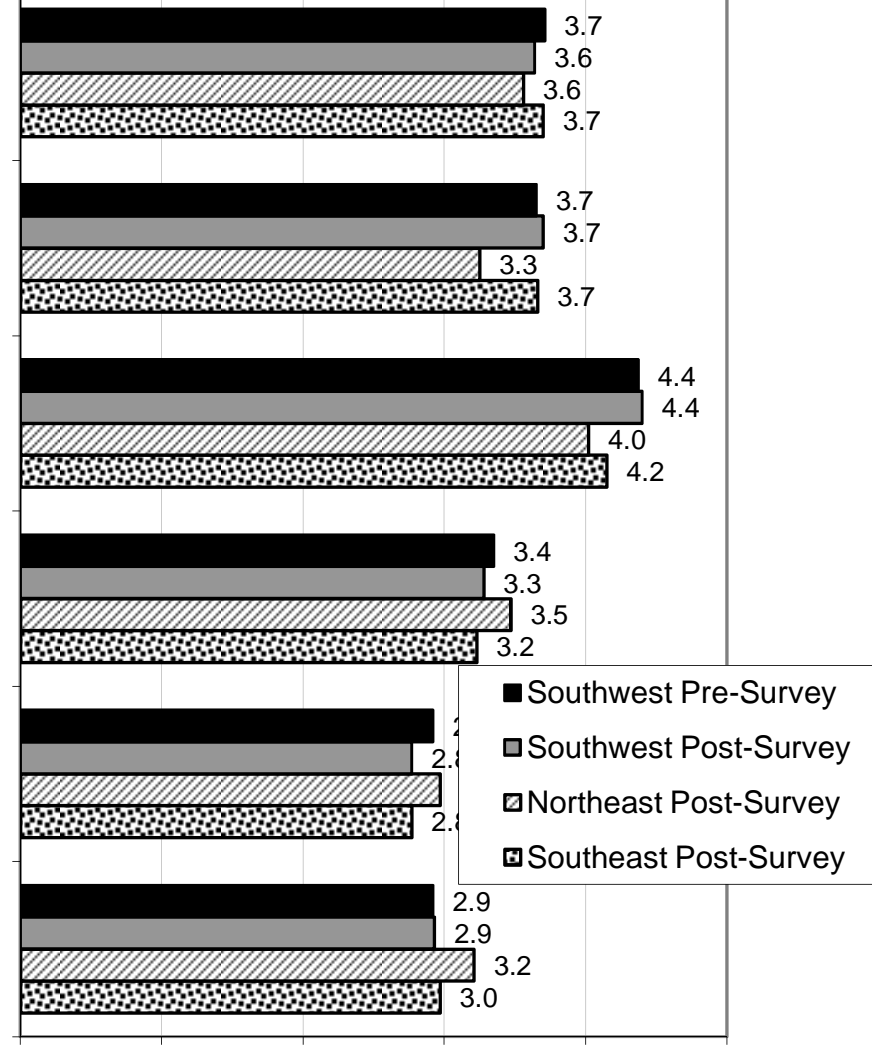

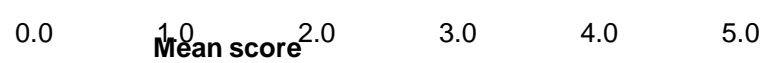

Figure 5 Respondents Attitudes towards Traveling by Car and Transit 
Table 26 Respondents' Mobility Attitudes

\begin{tabular}{|c|c|c|c|c|}
\hline \multirow[b]{2}{*}{ Measures of Attitudes } & \multicolumn{4}{|c|}{$\begin{array}{c}\text { Mean Score } \\
\text { (1=strongly disagree, } 5=\text { strongly agree) }\end{array}$} \\
\hline & $\begin{array}{l}\text { Southwest } \\
\text { Pre-Survey* }\end{array}$ & $\begin{array}{l}\text { Southwest } \\
\text { Post-Survey }\end{array}$ & $\begin{array}{l}\text { Northeast } \\
\text { Post-Survey }\end{array}$ & $\begin{array}{c}\text { Southeast } \\
\text { Post-Survey }\end{array}$ \\
\hline $\begin{array}{l}\text { Walking can sometimes be easier for me than } \\
\text { driving. }\end{array}$ & 3.44 & 3.28 & 3.96 & 3.69 \\
\hline $\begin{array}{l}\text { I prefer to walk rather than drive whenever } \\
\text { possible. }\end{array}$ & 3.73 & 3.59 & 3.88 & 3.63 \\
\hline I like walking. & 4.55 & 4.48 & 4.55 & 4.40 \\
\hline $\begin{array}{l}\text { Biking can sometimes be easier for me than } \\
\text { driving. }\end{array}$ & 2.25 & 2.26 & 2.94 & 2.69 \\
\hline $\begin{array}{l}\text { I prefer to bike rather than drive whenever } \\
\text { possible. }\end{array}$ & 2.44 & 2.49 & 3.08 & 2.75 \\
\hline I like riding a bike. & 3.19 & 3.37 & 3.68 & 3.29 \\
\hline $\begin{array}{l}\text { Public transit can sometimes be easier for me } \\
\text { than driving. }\end{array}$ & 2.92 & 2.93 & 3.21 & 2.97 \\
\hline $\begin{array}{l}\text { I prefer to take transit rather than drive whenever } \\
\text { possible. }\end{array}$ & 2.92 & 2.77 & 2.97 & 2.77 \\
\hline I like taking public transit. & 3.35 & 3.28 & 3.47 & 3.23 \\
\hline I need a car to do many of the things I like to do. & 4.37 & 4.40 & 4.02 & 4.15 \\
\hline Getting to work without a car is a hassle. & 3.65 & 3.70 & 3.25 & 3.66 \\
\hline I like driving. & 3.71 & 3.64 & 3.56 & 3.70 \\
\hline Traveling by car is safer overall than walking. & 2.61 & 2.86 & 2.14 & 2.37 \\
\hline $\begin{array}{l}\text { Traveling by car is safer overall than riding a } \\
\text { bicycle. }\end{array}$ & 4.03 & 4.04 & 3.78 & 3.96 \\
\hline $\begin{array}{l}\text { Traveling by car is safer overall than taking } \\
\text { public transit. }\end{array}$ & 2.32 & 2.47 & 2.16 & 2.29 \\
\hline I use my trip to or from work productively. & 3.77 & 3.71 & 3.99 & 3.91 \\
\hline $\begin{array}{l}\text { The trip to or from work is a useful transition } \\
\text { between home and work. }\end{array}$ & 3.64 & 3.73 & 3.73 & 3.74 \\
\hline $\begin{array}{l}\text { The only good thing about traveling is arriving } \\
\text { at your destination. }\end{array}$ & 2.22 & 2.26 & 2.33 & 2.47 \\
\hline Travel time is generally wasted time. & 2.83 & 2.81 & 2.74 & 2.73 \\
\hline $\begin{array}{l}\text { I prefer to organize my errands so that I make as } \\
\text { few trips as possible. }\end{array}$ & 4.80 & 4.77 & 4.73 & 4.81 \\
\hline $\begin{array}{l}\text { When I need to buy something, I usually prefer } \\
\text { to get it at the closest store possible. }\end{array}$ & 4.01 & 4.07 & 4.23 & 4.22 \\
\hline $\begin{array}{l}\text { I often use the telephone or the Internet to avoid } \\
\text { having to travel somewhere. }\end{array}$ & 4.26 & 4.36 & 4.27 & 4.15 \\
\hline $\begin{array}{l}\text { The price of gasoline affects the choices I make } \\
\text { about my daily travel. }\end{array}$ & 3.72 & 3.79 & 3.75 & 3.76 \\
\hline $\begin{array}{l}\text { I try to limit my driving to help improve air } \\
\text { quality. }\end{array}$ & 4.17 & 4.18 & 4.23 & 4.35 \\
\hline $\begin{array}{l}\text { Fuel efficiency is or would be an important } \\
\text { factor for me in choosing a vehicle. }\end{array}$ & 4.73 & 4.65 & 4.73 & 4.70 \\
\hline $\begin{array}{l}\text { The region needs to build more highways to } \\
\text { reduce traffic congestion. }\end{array}$ & 2.45 & 2.38 & 2.22 & 2.59 \\
\hline
\end{tabular}

*Only panel members included 
There are also some differences between respondents in the neighborhoods regarding social norms. These differences may help explain the larger changes in mode share demonstrated in the Northeast and Southeast neighborhoods after SmartTrips, relative to Southwest. For example, respondents in the Northeast target area were more likely to agree that people who are important to them think they should use a bike more, would support them in walking and biking more, walk and bike to places, and do not drive most places.

Table 27 Normative Beliefs by Neighborhood

\begin{tabular}{|c|c|c|c|c|}
\hline \multirow[b]{2}{*}{ Measures of Social Norms } & \multicolumn{4}{|c|}{$\begin{array}{c}\text { Mean Score } \\
(1=\text { strongly disagree, } 5=\text { strongly agree })\end{array}$} \\
\hline & $\begin{array}{c}\text { Southwest } \\
\text { Pre-Survey* }\end{array}$ & $\begin{array}{c}\text { Southwest } \\
\text { Post-Survey }\end{array}$ & $\begin{array}{c}\text { Northeast } \\
\text { Post-Survey }\end{array}$ & $\begin{array}{c}\text { Southeast } \\
\text { Post-Survey }\end{array}$ \\
\hline \multicolumn{5}{|l|}{$\begin{array}{l}\text { Most people who are important to me, for } \\
\text { example my family and friends, think I } \\
\text { should... }\end{array}$} \\
\hline use public transit more & 2.03 & 2.18 & 2.14 & 2.05 \\
\hline walk more & 2.52 & 2.63 & 2.69 & 2.68 \\
\hline use a bike more & 2.08 & 2.08 & 2.45 & 2.35 \\
\hline use my car less & 2.80 & 2.68 & 2.99 & 3.04 \\
\hline \multicolumn{5}{|l|}{$\begin{array}{l}\text { Most people who are important to me, for } \\
\text { example my family and friends, would support } \\
\text { me in ... }\end{array}$} \\
\hline ...using public transit more & 3.61 & 3.53 & 3.77 & 3.61 \\
\hline ... walking more & 3.72 & 3.76 & 3.91 & 3.79 \\
\hline ... using a bike more & 2.95 & 2.97 & 3.36 & 3.17 \\
\hline ... using my car less & 3.71 & 3.53 & 3.87 & 3.80 \\
\hline $\begin{array}{l}\text { Most of my family, friends, and co-workers } \\
\text { drive everywhere they need to go. }\end{array}$ & 3.81 & 3.71 & 3.32 & 3.77 \\
\hline $\begin{array}{l}\text { Many of my family, friends, and co-workers } \\
\text { walk to get to places, such as errands, shopping, } \\
\text { and work. }\end{array}$ & 2.51 & 2.65 & 3.07 & 2.77 \\
\hline $\begin{array}{l}\text { Many of my family, friends, and co-workers } \\
\text { ride a bike to get to places, such as errands, } \\
\text { shopping, and work. }\end{array}$ & 2.32 & 2.20 & 3.03 & 2.69 \\
\hline $\begin{array}{l}\text { Many of my family, friends, and co-workers use } \\
\text { transit regularly. }\end{array}$ & 2.96 & 2.97 & 3.14 & 2.94 \\
\hline
\end{tabular}

*Only panel members included

Consistent with the findings on attitudes and social norms, the respondents in the Northeast and Southeast target areas had higher levels of perceived behavioral control for using transit, walking and bicycling (Table 28). For example, Northeast and Southeast residents were more likely to agree that using transit, walking, or bicycling for daily travel from home would be easy. They were also more likely to agree that places they need to get to were within walking or biking distance from home or could be accessed by transit. 
Table 28 Perceived Behavioral Control by Neighborhood

\begin{tabular}{|c|c|c|c|c|}
\hline \multirow[b]{2}{*}{ Measures of Perceived Behavioral Control } & \multicolumn{4}{|c|}{$\begin{array}{c}\text { Mean Score } \\
(1=\text { strongly disagree, } 5=\text { strongly agree })\end{array}$} \\
\hline & $\begin{array}{l}\text { Southwest } \\
\text { pre-survey }\end{array}$ & $\begin{array}{c}\text { Southwest } \\
\text { post-survey }\end{array}$ & Northeast & Southeast \\
\hline $\begin{array}{l}\text { For me to use public transit for daily travel from home } \\
\text { would be easy. }\end{array}$ & 2.53 & 2.38 & 3.10 & 2.82 \\
\hline $\begin{array}{l}\text { For me to walk places for daily travel from home } \\
\text { would be easy. }\end{array}$ & 2.41 & 2.31 & 3.14 & 2.76 \\
\hline $\begin{array}{l}\text { For me to ride a bicycle for daily travel from home } \\
\text { would be easy. }\end{array}$ & 2.06 & 1.98 & 2.96 & 2.61 \\
\hline $\begin{array}{l}\text { For me to drive less for daily travel from home would } \\
\text { be easy. }\end{array}$ & 2.93 & 2.84 & 3.37 & 3.36 \\
\hline $\begin{array}{l}\text { I know where safe bike routes are in my } \\
\text { neighborhood. }\end{array}$ & 3.20 & 3.27 & 3.81 & 3.89 \\
\hline I know where I can walk safely in my neighborhood. & 4.33 & 4.34 & 4.81 & 4.69 \\
\hline I know where the buses that stop near my home go to. & 4.34 & 4.36 & 4.33 & 4.30 \\
\hline I know how often the buses stop near my home. & 3.65 & 3.64 & 3.73 & 3.62 \\
\hline $\begin{array}{l}\text { The buses that stop near my home go to the places I } \\
\text { need to get to regularly, such as work, school, or } \\
\text { shopping. }\end{array}$ & 2.86 & 2.77 & 3.27 & 3.07 \\
\hline $\begin{array}{l}\text { Many of the places I need to get to regularly are } \\
\text { within walking distance of my home. }\end{array}$ & 2.32 & 2.32 & 3.13 & 2.74 \\
\hline $\begin{array}{l}\text { Many of the places I need to get to regularly are } \\
\text { within biking distance of my home. }\end{array}$ & 3.03 & 2.93 & 3.83 & 3.43 \\
\hline $\begin{array}{l}\text { I have a bicycle at home that works that I could ride if } \\
\text { I wanted to. }\end{array}$ & 3.22 & 3.15 & 3.64 & 3.22 \\
\hline $\begin{array}{l}\text { I don't have time to use public transit instead of } \\
\text { driving. }\end{array}$ & 2.86 & 3.04 & 3.04 & 2.83 \\
\hline I don't have time to walk places instead of driving. & 3.03 & 2.98 & 2.77 & 2.82 \\
\hline I don't have time to bike places instead of driving. & 3.07 & 2.97 & 2.69 & 2.67 \\
\hline $\begin{array}{l}\text { The organization of my everyday life requires a high } \\
\text { level of mobility. }\end{array}$ & 3.45 & 3.56 & 3.38 & 3.33 \\
\hline
\end{tabular}

\subsubsection{TPB Models: Data Analysis Procedures}

To examine the relative contributions of attitudes, social norms and perceived behavioral control on behavioral outcomes, a series of multiple regressions were conducted. First, variables were created from individual items to represent attitudes, social norms, and perceived behavioral control for each model of transportation. The variable asking the likelihood of using the given mode of transportation over the next few weeks represented intentions to behave. The behavior variable was taken from reports of the past month's use of a given mode of transportation. For the Southwest sample, the attitude, norm, perceived behavioral control and intentions variables were taken from the pre-survey, with the behavior report coming from the post-survey. For the Northeast and Southeast, all variables were derived from the single, cross-sectional survey. 
The regressions were conducted in three steps consistent with Baron and Kenny (1986) and separately for each mode of transportation. First, behavior was regressed on attitudes, social norms and perceived behavioral control. Next, behavioral intentions are regressed on attitudes, social norms and perceived behavioral control. Finally, all variables are entered into the model together. According to the TPB Model (refer to Figure 1 on page 11), attitudes and social norms should be related to behavioral intentions, which are in turn related to behavior; however, the attitudes- and social norms-behavior relationships should be non-significant when intentions are included in the model. Perceived behavioral control, however, should display both a direct and indirect (through intensions) relationship with behavior.

\subsubsection{TPB Models: Southwest Target Area}

We predicted walking behavior in the past month at the post-survey using pre-survey intentions, attitudes, norms and perceived behavioral control (Table 29). In the first model, attitudes and perceived behavioral control predicted walking behavior; however, social norms did not. All three variables predicted intentions to walk, perceived behavioral control being the strongest of the predictors and social norms being the weakest. Finally, in the third model, we found that intentions to walk significantly predicted walking behavior, as did perceived behavioral control for walking. Contrary to expectation, attitudes were still significantly related to walking behavior, even when controlling for intentions to walk. Thus attitudes demonstrated both a direct relationship with walking behavior, as well as an indirect relationship through intensions to walk. Consistent with the TPB model, intentions to walk partially mediated the association between pro-walking attitudes and perceived behavioral control for walking and walking behavior. Normative beliefs were also indirectly related to walking by predicting intentions to walk, which were in turn predictive of walking behavior. The TPB model accounted for $45 \%$ of the explained variance in walking behavior.

Table 29: TPB Models of Walking, Southwest

\begin{tabular}{lccc}
\hline & $\begin{array}{c}\text { Model 1 } \\
\text { Past 30-day } \\
\text { Walking }\end{array}$ & $\begin{array}{c}\text { Model 2 } \\
\text { Intentions to walk }\end{array}$ & $\begin{array}{c}\text { Model 3 } \\
\text { Past 30-day Walking }\end{array}$ \\
\hline Attitudes & $.33^{* *}$ & $.26^{* *}$ & $.25^{* *}$ \\
\hline Social Norms & .02 & $.15^{* *}$ &. .02 \\
\hline Perceived Behavioral Control & $.41^{* *}$ & $.39^{* *}$ & $.31^{* *}$ \\
\hline Intentions to walk & & & $.25^{* *}$ \\
\hline$R^{2}$ & .43 & .43 & .45 \\
\hline
\end{tabular}

Next, we predicted past transit use in the past month at the post-survey from pre-survey intentions, attitudes, norms and perceived behavioral control (Table 30). All predictors (i.e., attitudes, social norms and perceived behavioral control) were significantly related to transit use in Model 1 and intentions to use transit (Model 2). When intentions were included in Model 3, as a predictor, we see that attitudes and perceived behavioral control remained significant as predictors of transit use. Thus, intentions fully mediated the relationship between normative beliefs and transit use and partially mediated the relationships between attitudinal beliefs and perceived behavioral control and transit use. The TPB model explains 53\% of post-survey transit 
use. In contrast with walking behavior, normative beliefs, attitudes, and perceived behavioral control had similar magnitudes of influence on intentions.

Table 30: TPB Models of Transit Use, Southwest

\begin{tabular}{lccc}
\hline & $\begin{array}{c}\text { Model 1 } \\
\text { Past 30-day Transit } \\
\text { Use }\end{array}$ & $\begin{array}{c}\text { Model 2 } \\
\text { Intentions to use } \\
\text { transit }\end{array}$ & $\begin{array}{c}\text { Model 3 } \\
\text { Past 30-day Transit } \\
\text { Use }\end{array}$ \\
\hline Attitudes & $.37^{* *}$ & $.28^{* *}$ & $.22^{*}$ \\
\hline Social Norms & $.14^{*}$ & $.26^{* *}$ & .05 \\
\hline Perceived Behavioral Control & $.26^{* *}$ & $.30^{* *}$ & $.13^{*}$ \\
\hline Intentions & & & $.43^{* *}$ \\
\hline$R^{2}$ & .46 & .50 & .53 \\
\hline
\end{tabular}

Finally, we predicted bicycle use in the past month at the post-survey using pre-survey intentions, attitudes, norms and perceived behavioral control (Table 31). Attitudes and perceived behavioral control were related to bicycling behavior in Model 1, and all three predictors (including social norms) were related to intentions to bicycle (Model 2). Finally, when intentions were included in the model (Model 3), attitudes and perceived behavioral control both retained a significant though smaller relationship to behavior. Thus, intentions to bicycle partially mediated the relationships between attitudinal beliefs and perceived behavioral control and bicycling behavior. Normative beliefs were also indirectly related to bicycling through intention. The TPB model explained 55\% of bicycling use. In contrast to the walking and transit models, attitudes had the largest influence on intentions, with a coefficient (0.45) about twice as large as for perceived behavioral control $(0.23)$ and three times that of normative beliefs $(0.15)$.

Table 31: TPB Models of Bicycling, Southwest

\begin{tabular}{lccc}
\hline & $\begin{array}{c}\text { Model 1 } \\
\text { Past 30-day Bicycling }\end{array}$ & $\begin{array}{c}\text { Model 3 } \\
\text { Model 2 } \\
\text { Intentions to Bicycle }\end{array}$ & $\begin{array}{c}\text { Past 30-day } \\
\text { Bicycling }\end{array}$ \\
\hline Attitudes & $.46^{* *}$ & $.45^{* *}$ & $.21^{* *}$ \\
\hline Social Norms & .05 & $.15^{* *}$ & .00 \\
\hline Perceived Behavioral Control & $.26^{* *}$ & $.23^{* *}$ & $.18^{* *}$ \\
\hline Intentions & & & $.45^{* *}$ \\
\hline$R^{2}$ & .47 & .53 & .55 \\
\hline
\end{tabular}

\subsubsection{TPB Models: Northeast and Southeast Target Area}

The following analyses were comprised of cross-sectional analyses conducted approximately at the time of the post-survey in Southwest. We include post-only analyses from Southwest as a point of comparison to the other two regions. We predicted past 30-day walking behavior from the three TPB components (Table 32). 
We also predicted intentions to engage in future walking behavior. Both attitudes and perceived behavioral control were relatively strong predictors of walking and intentions to walk. Social norms for walking was not a significant predictor of walking behavior among Southeast respondents, but was significant for Northeast and Southwest respondents. The TPB variables explained between $45-51 \%$ of variance in walking behavior and $48-58 \%$ of intentions to walk.

Table 32: TPB Models of Walking, Northeast and Southeast compared to Southwest

\begin{tabular}{lll}
\hline & $\begin{array}{c}\text { Past 30-day } \\
\text { Walking }\end{array}$ & Intentions to walk \\
\hline Northeast & & \\
\hline Attitudes & $.39^{* * *}$ & $.31^{* * *}$ \\
\hline Social Norms & $.17^{* * *}$ & $.09^{*}$ \\
\hline Perceived Behavioral Control & $.29^{* *}$ & $.48^{* * *}$ \\
\hline$R^{2}$ & .51 & .58 \\
\hline Southeast & & \\
\hline Attitudes & $.42^{* * *}$ & $.36^{* * *}$ \\
\hline Social Norms & .09 & .09 \\
\hline Perceived Behavioral Control & $.28^{* * *}$ & $.36^{* * *}$ \\
\hline$R^{2}$ & .45 & .48 \\
\hline Southwest & & $.38^{* * *}$ \\
\hline Attitudes & $.27^{* * *}$ & $.18^{* * *}$ \\
\hline Social Norms & $.12^{*}$ & $.30^{* * *}$ \\
\hline Perceived Behavioral Control & $.45^{* * *}$ & .54 \\
\hline$R^{2}$ & .51 & \\
\hline
\end{tabular}

We predicted past 30-day transit use from the three TPB components (Table 33). We also predicted intentions to engage in future transit use. In these models, TPB variables consistently predicted past 30-day transit use across city quadrants, wherein attitudes and perceived behavioral control but not social norms predicted transit use. All variables, including social norms, predicted intentions to use transit, however. Explained variance ranged from $43-51 \%$ for past 30-day transit use, and 49-56\% for intentions to use transit. 
Table 33: TPB Models of Transit Use, Northeast and Southeast compared to Southwest

\begin{tabular}{lll}
\hline & $\begin{array}{c}\text { Past 30-day Transit } \\
\text { Use }\end{array}$ & $\begin{array}{c}\text { Intentions to use } \\
\text { Transit }\end{array}$ \\
\hline Northeast & & \\
\hline Attitudes & $.44^{* * *}$ & $.43^{* * *}$ \\
\hline Social Norms & .09 & $.17^{* * *}$ \\
\hline Perceived Behavioral Control & $.25^{* * *}$ & $.25^{* * *}$ \\
\hline$R^{2}$ & .44 & .51 \\
\hline Southeast & & \\
\hline Attitudes & $.43^{* * *}$ & $.36^{* * *}$ \\
\hline Social Norms & .10 & $.10^{*}$ \\
\hline Perceived Behavioral Control & $.22^{* * *}$ & $.35^{* * *}$ \\
\hline$R^{2}$ & .43 & .49 \\
\hline Southwest & & \\
\hline Attitudes & $.50^{* * *}$ & $.48^{* * *}$ \\
\hline Social Norms & .08 & $.17^{* *}$ \\
\hline Perceived Behavioral Control & $.23^{* * *}$ & $.21^{* * *}$ \\
\hline$R^{2}$ & .51 & .56 \\
\hline
\end{tabular}

We predicted past 30-day bicycling from the three TPB components (Table 34). We also predicted intentions to engage in future bicycling. All models were consistent across city quadrants and across outcome variables. Specifically, attitudes were the strongest predictor of intentions to bicycle and bicycling behavior. Perceived behavioral control also significantly predicted intentions and behavior but to a lesser degree. Social norms did not significantly predict either outcome. Models explained between 51-59\% of variance in bicycling, and 55-64\% of intentions to bicycle.

Table 34: TPB Models of Bicycling, Northeast and Southeast compared to Southwest

\begin{tabular}{lll}
\hline & Past 30-day Bicycling & Intentions to bicycle \\
\hline Northeast & & \\
\hline Attitudes & $.67^{* * *}$ & $.60^{* * *}$ \\
\hline Social Norms & .04 & .02 \\
\hline Perceived Behavioral Control & $.11^{*}$ & $.26^{* * *}$ \\
\hline$R^{2}$ & .59 & .64 \\
\hline Southeast & & \\
\hline Attitudes & $.66^{* * *}$ & $.59^{* * *}$ \\
\hline Social Norms & .08 & .05 \\
\hline Perceived Behavioral Control & $.16^{* *}$ & $.17^{* *}$ \\
\hline$R^{2}$ & .51 & .56 \\
\hline Southwest & & $.43^{* * *}$ \\
\hline Attitudes & $.51^{* * *}$ & .10 \\
\hline Social Norms & .01 & $.34^{* * *}$ \\
\hline Perceived Behavioral Control & $.31^{* * *}$ & .55 \\
\hline$R^{2}$ & .51 & \\
\hline
\end{tabular}




\subsection{CONCLUSIONS}

\subsection{KEY FINDINGS}

\subsubsection{Effectiveness of Individualized Marketing}

The pre- and post-surveys of the panel of residents in the Southwest target area found few shifts in travel behavior consistent with the intentions of the SmartTrips program. There was a significant drop in the share of weekday trips made driving alone. However, some of this drop may be attributed to the large increase in gas prices between the two surveys. The daily trip data indicated that there may have been an increase in walking, though the difference was not statistically significant. There was, however, a significant increase in the share of respondents who said they had biked in the past month.

The findings from the Northeast and Southeast target areas were more positive with respect to the SmartTrips program. Those surveys found that the share of daily trips made driving alone, walking, and bicycling were comparable to that found in the previous follow-up surveys, still significantly lower (for driving alone) or higher (for walking and bicycling) than the pre-surveys. This may indicate that the SmartTrips program was effective at changing behavior for a longer time period than previously measured. However, it is difficult to attribute causality directly to the program.

The differences between people who had participated in the SmartTrips program, measured by whether they ordered program materials, and those who did not indicates that the program may have contributed to the changes in travel behavior. Southwest respondents who ordered materials were significantly more likely to have taken transit or biked from home once a month or more in the past month. Northeast residents who ordered materials were significantly more likely to have taken transit in the past month. Southeast respondents who ordered materials were significantly more likely to have taken transit or walked in the past month. However, there was only one significant difference in daily trips by mode between those who ordered materials and those who did not. Southwest residents who ordered materials made more bike trips on the previous day than those who had not ordered materials. However, there is also some evidence that people who ordered materials may have been more likely to use alternative modes before the program.

\subsubsection{Application of TPB}

The TPB models were effective at explaining travel behavior. The models showed that attitudes, social norms, and perceived behavioral control explain a large share (45-55\%) of the variance in travel behavior. The relative influence of each component of the model differed some by mode. For example, in the Southwest target area, attitudes had the largest influence on bicycling, while perceived behavioral control seemed more important in predicting walking behavior. In most cases, the models indicated that social norms do not influence behavior very much. 
Some of the differences in the changes in travel mode between the three target areas may be explained by components of the TPB. Residents in the Northeast and Southeast target areas scored higher on several of the indicators of positive attitudes towards walking and bicycling, social norms related to using other modes, and perceived behavioral control for using transit, walking, and bicycling. The data from the Southwest panel, however, did not indicate many significant changes in these factors in the direction intended by the program. In other words, the survey did not show that the program affected these factors significantly.

Yet, given that we demonstrated an ability to significantly predict behavior, even across time (in the Southwest panel data), we are in a better position to create effective interventions in the future (see Albarracín, Johnson, Fishbein, \& Muellerleile, 2001). Often, the decision to concentrate on attitudes or norms when designing an intervention is made based on the practitioners intuition, as opposed to solid empirical evidence (Albarracín et al., 2001). Based on our research, efforts that focus on social norms to influence travel behavior may be considerably less effective than those that include attitudinal and behavioral control components. Sensitivity to regional characteristics and the specific travel mode that is the target of interest is also warranted. Moreover, the TPB demonstrates the efficacy of combining all three components to maximally influence behavior change. As a case in point, Bamberg et al. (2003) demonstrated that targeting interventions to all three components (i.e., attitudes, social norms and perceived behavioral control) in an effort to increase bus use is effective at changing those components and consequently behavioral intentions and actual behavior.

\subsubsection{Policy Implications}

The findings from the Northeast and Southeast target areas support previous research that individualized marketing programs can be effective at changing people's travel behavior. The findings indicate that the benefits of the programs may extend beyond one year and up to at least two years. However, the findings from the Southwest target area indicate that the programs may not be as effective in all environments. The programs may be more effective in neighborhoods with a physical environment more conducive to walking, bicycling, and transit. Several of the differences in perceived behavioral control were related to the physical environment, such as having places within walking and biking distance. Public policy and investment can influence the location of destinations near residential areas. In addition, the benefits of investing in making a community more walkable and bikeable and improving transit service might be increased through the use of such marketing programs.

The research also found that attitudes, norms, and perceptions play a large role in travel decisions. To be most effective, individualized marketing programs need to influence these factors. This research did not detect changes in these factors before and after the program and, therefore, cannot shed light on how to influence those factors. However, the research did show which factors had a larger effect on the decision to use different travel modes. This can provide some guidance on which factors to target in marketing programs.

\subsection{LIMITATIONS AND FUTURE RESEARCH}

There are several limitations that arose with the survey data and methods. For example, the lack of findings of significant changes or differences may in some instances be due to the sample size, 
particularly for the Southwest panel. There were 288 people that completed both surveys in the Southwest target area. Of those, only $18 \%$ participated in the program by ordering materials. That small number made it more difficult to detect differences between participants and nonparticipants. The questions measuring intentions may not have done a very good job of measuring intention. Most of the responses were in two of the five categories, limiting the variation. The large increase in gas prices between the pre- and post-surveys also creates a confounding factor. Using a control group would have helped in this regard.

More analysis of the data is necessary to explore what roles the physical environment and access to infrastructure (e.g., sidewalks, bike lanes, transit) and destinations (e.g., shops and restaurants). This can be done by developing measures of each respondent's environment using their home location, which was collected on the survey. These variables, along with demographics, can then be added to the models with the TPB variables to understand the relative contribution of each factor. Additional analysis should also include weather as a factor. 


\subsection{REFERENCES}

Ajzen, I. (1985), From intentions to actions: A theory of planned behaviour. In J Kuhl, J Beckman (Eds), Action control: From cognition to behaviour, New York: Springer, (pp 11-39).

Ajzen, I. (1991). The theory of planned behavior. Organizational Behavior and Human Decision Processes, 50, 179-211.

Albarracín, D., Johnson, B.T., Fishbein, M., \& Muellerleile, P.A. (2001). Theories of reasoned action and planned behavior as models of condom use: A meta-analysis. Psychological Bulletin, 127 (1), 142-161.

Armitage, C.J. \& Arden, M.A. (2008). How useful are the stages of change for targeting interventions? Randomized test of a brief intervention to reduce smoking. Health Psychology 27, 789-798.

Armitage, C.J., \& Conner, M. (2001). Efficacy of the theory of planned behaviour: A metaanalytic review. British Journal of Social Psychology, 40, 471-499.

Arterburn, D., Westbrook, E.O., Wiese, C.J., Ludman, E.J., Grossman, D.C., Fishman, P.A., Finkelstein, E.A., Jeffery, R.W., \& Drewnowski, A. (2008). Insurance coverage and incentives for weight loss among adults with metabolic syndrome. Obesity, 16, 70-76.

Australian Greenhouse Office, ;. 2005. Evaluation of Austalian TravelSmart Projects in the ACT, South Australia, Queensland, Victoris and Western Australia: 2001-2005. Department of the Environment and Heritage.

Bamberg, Sebastian, Daniel Rölle, and Christoph Weber. 2003. Does habitual car use not lead to more resistance to change of travel mode? Transportation 30 (1):97-108.

Bamberg, Sebastian, Icek Ajzen, and Peter Schmidt. 2003. Choice of Travel Mode in the Theory of Planned Behavior: The Roles of Past Behavior, Habit, and Reasoned Action. Basic \& Applied Social Psychology 25 (3):175.

Bamberg, Sebastian, Marcel Hunecke, and Anke Blobaum. 2007. Social context, personal norms and the use of public transportation: Two field studies. Journal of Environmental Psychology 27 (3):190-203.

Bandura, A. (1986). Social foundations of thought and action: A social cognitive theory. Englewood Cliffs, NJ: Prentice Hall.

Bandura, A. (1997). Self-efficacy: The exercise of control. New York: Freeman.

Bandura. A. (1977). Self-efficacy: Toward a unifying theory of behavioral change. Psychological Review, 84, 191-215.

Baron, R. M., \& Kenny, D. A. (1986). The moderator-mediator variable distinction in social psychological research: Conceptual, strategic and statistical considerations. Journal of Personality and Social Psychology, 51, 1173-1182. 
Beale, J. \& Bonsall, P. (2007). Marketing in the bus industry: A psychological interpretation of some attitudinal and behavioural outcomes. Transportation Research Part F: Traffic Psychology and Behaviour, 10, 271-287.

Blanchard, C.M., Kupperman, J., Sparling, P., Nehl, E., Rhodes, R.E., Courneya, K.S., Baker, F., \& Rupp, J.C. (2008). Ethnicity and the theory of planned behavior in an exercise context: A mediation and moderation perspective. Psychology of Sport and Exercise 9, 527-545.

Blue, C. 1995. The predictive capacity of the theory of reasoned action and the theory of planned behavior in exercise research: An integrated literature review. Research in Nursing \& Health 18:105-121.

Brog, Werner, and Franz Barta. 2007. National Demonstration Project (FTA): Individualized Marketing Demonstration Program. In 86th Annual Meeting of the Transportation Research Board. Washington, DC: Transportaiton Research Board.

Brog, Werner. 1998. Individualized Marketing Implications for Transportation Demand Management. Transportation Research Record 1618:116-121.

City of Portland Office of Transportation. 2005. Eastside Hub Target Area Program Comprehensive Evaluation Report. Portland, OR: City of Portland.

2006. SmartTrips Northeast Hub Comprehensive Evaluation Report. Portland, OR: City of Portland.

Coureya, Kerry S., and Edward McAuley. 1994. Are there different determinants of the frequency, intensity, and duration of physical activity? Behavioral Medicine 20 (2):84

Deci, E. L., \& Ryan, R. M. (1985). Intrinsic motivation and self-determination in human behavior. New York: Plenum Publishing Co.

Ferguson, Eric. (1997). The rise and fall of the American carpool: 1970-1990. Transportation 24 (4):349-376.

Festinger, L., \& Carlsmith, J.M. (1959). Cognitive consequences of forced compliance. Journal of Abnormal and Social Psychology, 58, 203-210.

Forster, J.L., Jeffery, R.W., Schmid, T.L., \& Kramer, F.M. (1988). Preventing weight gain in adults: A pound of prevention. Health Psychology, 7, 515-525.

Gärling, T., Gillholm, R., \& Gärling, A. (1998). Reintroducing attitude theory in travel behavior research: The validity of an interactive interview procedure to predict car use. Transportation, 25(2), 129-146.

Greene, D. Sternberg, B. and Lepper, M. R. (1976) Overjustification in a token economy, Journal of Personality and Social Psychology, 34, 1219-1234.

Handy, S., X. Y. Cao, and P. Mokhtarian. 2005. Correlation or causality between the built environment and travel behavior? Evidence from Northern California. Transportation Research Part D-Transport and Environment 10 (6):427-444.

Hausenblas, H.A, A.V Carron, and D.E. Mack. 1997. Application of the theories of reasoned action and planned behavior to exercise behavior: A meta-analysis. Journal of Sport \& Exercise Psychology 19:36-51. 
Hausenblas, H.A., Carron, A.V., \& Mack, D.E. (1997). Application of the theories of reasoned action and planned behavior to exercise behavior: A meta-analysis. Journal of Sport \& Exercise Psychology, 19, 36-51.

Haustein, Sonja, and Marcel Hunecke. 2007. Reduced Use of Environmentally Friendly Modes of Transportation Caused by Perceived Mobility Necessities: An Extension of the Theory of Planned Behavior. Journal of Applied Social Psychology 37 (8):1856-1883.

Herman, C.W., Musich, S., Lu, C., Sill, S., Young, J.M., \& Edington, D.W. (2006). Effectiveness of an incentive-based online physical activity intervention on employee health status. Journal of Occupational \& Environmental Medicine, 48, 889-895.

Janis, I.L. , and L. Mann. 1977. Decision making: A psychological analysis of conflict choice and commitment. New York: Free Press.

Kitamura, Ryuichi, Patricia L. Mokhtarian, and Laura Laidet. 1997. A micro-analysis of land use and travel in five neighborhoods in the San Francisco Bay Area. Transportation 24:125158.

Kiviniemi, M.T., Voss-Humke, A.M., \& Seifert, A.L. (2007). How do I feel about the behavior? The interplay of affective associations with behaviors and cognitive beliefs as influences on physical activity behavior. Health Psychology 26(2), 152-158.

Lajunen, Timo, and Mikko Rasanen. 2004. Can social psychological models be used to promote bicycle helmet use among teenagers? A comparison of the Health Belief Model, Theory of Planned Behavior and the Locus of Control. Journal of Safety Research 35 (1):115.

MELE Associates, Inc. 2006. Federal Transit Administration's Individualized Marketing Demonstration Program (IMDP) Final Report. Washington, DC: Federal Transit Administration.

Meyer, M. D. 1999. Demand management as an element of transportation policy: using carrots and sticks to influence travel behavior. Transportation Research Part a-Policy and Practice 33 (7-8):575-599.

Norman, Paul, and Lawrence Smith. 1995. The theory of planned behaviour and exercise: an investigation into the role of prior behaviour, behavioural intentions and attitude variability. European Journal of Social Psychology 25 (4):403-415.

Portland Office of Transportation. 2007. SmartTrips Southeast Final Report. Portland, OR: City of Portland.

Prochaska, J.O, W.F Velicer, J.S Rossi, M.G Goldstein, B.H Marcus, W Rakowski, C Fiore, L.L Harlow, C.A Redding, D Rosenbloom, and S.R. Rossi. 1994. Stages of change and decisional balance for 12 problem behaviors. Health Psychology 13:39-46.

Prochaska, J.O. 1994. Strong and weak principles for progressing from pre-contemplation to action on the basis of 12 problem behaviors. Health Psychology 13:47-51.

Prochaska, J.O., DiClemente, C.C., \& Norcross, J.C. (1992). In search of how people change: Applications to addictive behaviors. American Psychologist, 47, 1102-1114. 
Prochaska, J.O., Velicer, W.F., Rossi, J.S., Goldstein, M.G., Marcus, B.H., Rakowski, W., Fiore, C., Harlow, L.L., Redding, C.A., Rosenbloom, D., Rossi, S.R. (1994). Stages of change and decisional balance for 12 problem behaviors. Health Psychology, 13(1), 39-46.

Reed, G. R., Velicer, W. F., Prochaska, J. O., Rossi, J. S., \& Marcus, B. H. (1997). What makes a good algorithm: Examples from regular exercise. American Journal of Health Promotion, 12, 57-66.

Rivera, Dylan, 2008. "Calls grow louder for a safer MAX," Oregonian, Page A1.

Ryan, R. M., \& Deci, E. L. (2007). Active human nature: self-determination theory and the promotion and maintenance of sport, Exercise, and health. In M. S. Hagger \& N. L. D. Chatzisarantis (Eds.), Intrinsic motivation and self-determination in exercise and sport (pp. 1-19). Human Kinetics Europe Ltd.

Socialdata America. 2005. Portland Interstate Large-Scale Individualized Marketing TravelSmart Project. Portland, OR: City of Portland Transportation Options.

Staats, A. W., and Staats, C. K. Attitudes established by classical conditioning . Journal of Abnormal and Social Psychology, 1958, 57, 37-40.

Stopher, Peter, Stephen Greaves, Camden FitzGerald, Natalie Swann, and Alan Perkins. 2006. A pilot survey of a panel approach to evaluating TravelSmart initiatives. Road \& transport research 15:p. 21-34.

VanRyn, M., L. A. Lytle, and J. P. Kirscht. 1996. A test of the theory of planned behavior for two health-related practices. Journal of Applied Social Psychology 26 (10):871-883.

Weinstein, N.D., Rothman, A.J., \& Sutton, S.R. (1998). Stage theories of health behavior: Conceptual and methodological issues. Health Psychology, 17, 290-299. 


\subsection{APPENDIX: SURVEY QUESTIONNAIRES}

\subsection{TRAVEL DAY QUESTIONS}

\section{Included on all surveys}

In order to get an idea of the different modes of transportation that Portland residents use we're going to ask you to think about all the places you went yesterday. We want to know a general description of the places you went and the modes of transportation you used. For example, if you drove your child to school yesterday and from there drove to work, that would be two trips, one to drive your child to school and one to drive to work. Or if you took the bus to go shopping, you can just say, "I took the bus to go shopping." Do you have any questions?

So, please think about where you went yesterday. What was the first place you went?

INTERVIEWER NOTES:Make sure R returns home as last trip, unless they did end up in another location if $r$ did not return home on last trip, add io note if $r$ not in Portland full day, add IO note

If $\mathrm{R}$ went home, record new trip with "RETURNED HOME" codes and record same mode as was just used.

The end of each day is at 2:00am. Please don't include trips after this time.As Needed Say, "What was the purpose of the trip?"

Each stop at a DIFFERENT ADDRESS qualifies as a trip.

Work, or work related (work related could include a business trip)

School/education

Leisure (movie, eating, coffee, visiting, etc.)

Shopping/Errands

Fitness, exercise (walk, walking dog, bike ride, etc.)

Church

Medical, Dental, Vet

Pick-up Drop-off (driving someone else, including child to school or dog to daycare)

Return to work

Returned home..... from work or work-related

Returned home..... from school

Returned home..... from leisure

Returned home..... from shopping/errands

Returned home.... from fitness, exercise

Returned home..... from pick-up/drop-off

Returned home..... from other (please specify)

Other (please specify)

Returned home.... from church

Returned home.... from medical, dental, vet 
$\mathrm{R}$ not in Portland area for the entire day yesterday

Don't Know

Refused

and what mode of transportation did you use?

Bus

Taxi

Auto (drive alone)

Auto (drive with someone or a passenger)

Motorcycle, Scooter

Bike

Walk/Skateboard/Rollerblade/Wheelchair

Other (please specify)

Don't Know

Refused

Repeated up to 20 times to gather trip data

\subsection{CITY OF PORTLAND QUESTIONS}

\section{Included on Southwest Surveys only}

\begin{tabular}{|l|l|}
\hline Questions & Potential Responses \\
\hline $\begin{array}{l}\text { Now I am going to read you a couple of statements. For } \\
\text { each statement, please tell me if you strongly disagree, } \\
\text { somewhat disagree, somewhat agree, or strongly agree. }\end{array}$ & $\begin{array}{l}\text { Strongly Disagree } \\
\text { Somewhat Disagree } \\
\text { Somewhat Agree }\end{array}$ \\
\hline $\begin{array}{l}\text { It is important to me to do everything I can to reduce my } \\
\text { personal impact on global warming. }\end{array}$ & Strongly Agree \\
\cline { 1 - 1 } $\begin{array}{l}\text { We all need to take steps to reduce our dependence on } \\
\text { the world's finite oil supply. }\end{array}$ & $\begin{array}{l}\text { Don't Know } \\
\text { Refused }\end{array}$ \\
\hline $\begin{array}{l}\text { The concept of global warming has a significant impact } \\
\text { on which modes of transportation I use. }\end{array}$ \\
\cline { 1 - 1 } $\begin{array}{l}\text { The concept of peak oil has a significant impact on } \\
\text { which modes of transportation I use. }\end{array}$ \\
\hline
\end{tabular}

In the past six months, do you remember reading, seeing, or hearing any information from the City of Portland specifically about alternative means of transportation available in your neighborhood?

No

Yes

Don't Remember/Don't Know

Refused 


\subsection{PSU BELIEFS AND ATTITUDE QUESTIONS}

\section{Included on all surveys}

\begin{tabular}{|c|c|}
\hline Questions & Potential Responses \\
\hline \multicolumn{2}{|c|}{$\begin{array}{l}\text { We would also like to ask about your preferences with respect to daily travel. For each, please } \\
\text { tell me if you strongly disagree, somewhat disagree, neither agree nor disagree, somewhat } \\
\text { agree, or strongly agree. }\end{array}$} \\
\hline Walking can sometimes be easier for me than driving. & \multirow{25}{*}{$\begin{array}{l}\text { Strongly Disagree } \\
\text { Somewhat Disagree } \\
\text { Neither Agree Nor } \\
\quad \text { Disagree } \\
\text { Somewhat Agree } \\
\text { Strongly Agree } \\
\\
\text { Don't know } \\
\text { Refused }\end{array}$} \\
\hline Travel time is generally wasted time. & \\
\hline I prefer to take transit rather than drive whenever possible. & \\
\hline I like riding a bike. & \\
\hline $\begin{array}{l}\text { I use my trip to or from work productively. INTERVIEWER NOTE: If R } \\
\text { mentions that s/he is not employed and cannot answer this question, probe by saying: } \\
\text { "This question is geared towards your attitude about travel. Could you answer it about } \\
\text { other places you travel to?" }\end{array}$ & \\
\hline I like taking public transit. & \\
\hline Traveling by car is safer overall than walking. & \\
\hline I need a car to do many of the things I like to do. & \\
\hline I prefer to walk rather than drive whenever possible. & \\
\hline I like driving. & \\
\hline I prefer to bike rather than drive whenever possible. & \\
\hline Traveling by car is safer overall than riding a bicycle. & \\
\hline Public transit can sometimes be easier for me than driving. & \\
\hline I try to limit my driving to help improve air quality. & \\
\hline Traveling by car is safer overall than taking public transit. & \\
\hline $\begin{array}{l}\text { Getting to work without a car is a hassle. INTERVIEWER NOTE: If R } \\
\text { mentions that s/he is not employed and cannot answer this question, probe by saying: } \\
\text { "This question is geared towards your attitude about travel. Could you answer it about } \\
\text { other places you travel to?" }\end{array}$ & \\
\hline I like walking. & \\
\hline Biking can sometimes be easier for me than driving. & \\
\hline The only good thing about traveling is arriving at your destination. & \\
\hline I prefer to organize my errands so that I make as few trips as possible. & \\
\hline The price of gasoline affects the choices I make about my daily travel. & \\
\hline $\begin{array}{l}\text { The trip to or from work is a useful transition between home and work. } \\
\text { INTERVIEWER NOTE: If R mentions that s/he is not employed and cannot answer } \\
\text { this question, probe by saying: "This question is geared towards your attitude about } \\
\text { travel. Could you answer it about other places you travel to?" }\end{array}$ & \\
\hline $\begin{array}{l}\text { Fuel efficiency is or would be an important factor for me in choosing a } \\
\text { vehicle. }\end{array}$ & \\
\hline $\begin{array}{l}\text { I often use the telephone or the Internet to avoid having to travel } \\
\text { somewhere. }\end{array}$ & \\
\hline $\begin{array}{l}\text { When I need to buy something, I usually prefer to get it at the closest } \\
\text { store possible. }\end{array}$ & \\
\hline The region needs to build more highways to reduce traffic congestion. & \\
\hline
\end{tabular}




\begin{tabular}{|c|c|}
\hline $\begin{array}{l}\text { Again, please indicate the extent to which you agree or disagree with } \\
\text { each of the following statements. }\end{array}$ & \\
\hline $\begin{array}{l}\text { Most people who are important to me, for example my family and } \\
\text { friends, think I should use public transit more. }\end{array}$ & \\
\hline What about walking more? & \\
\hline What about using a bike more? & \\
\hline What about using your car less? & \\
\hline $\begin{array}{l}\text { Most people who are important to me, for example my family and } \\
\text { friends, would support me in using public transit more. }\end{array}$ & \\
\hline What about walking more? & \\
\hline What about using a bike more? & \\
\hline What about using your car less? & \\
\hline $\begin{array}{l}\text { Most of my family, friends, and co-workers drive everywhere they } \\
\text { need to go. }\end{array}$ & \\
\hline $\begin{array}{l}\text { Many of my family, friends, and co-workers walk to get to places, such } \\
\text { as errands, shopping, and work. }\end{array}$ & \\
\hline $\begin{array}{l}\text { Many of my family, friends, and co-workers ride a bike to get to places, } \\
\text { such as errands, shopping, and work. }\end{array}$ & \\
\hline Many of my family, friends, and co-workers use transit regularly. & \\
\hline $\begin{array}{l}\text { I feel a personal obligation to use public transit instead of the car for } \\
\text { everyday travel. }\end{array}$ & \\
\hline What about walking instead of driving? & \\
\hline What about bicycling instead of driving? & \\
\hline I feel a personal obligation to drive my car less for everyday travel. & \\
\hline For me to use public transit for daily travel from home would be easy. & \\
\hline For me to walk places for daily travel from home would be easy. & \\
\hline For me to ride a bicycle for daily travel from home would be easy. & \\
\hline For me to drive less for daily travel from home would be easy. & \\
\hline I know where safe bike routes are in my neighborhood. & \\
\hline I know where I can walk safely in my neighborhood. & \\
\hline I know where the buses that stop near my home go to. & \\
\hline I know how often the buses stop near my home. & \\
\hline $\begin{array}{l}\text { The buses that stop near my home go to the places I need to get to } \\
\text { regularly, such as work, school, or shopping. }\end{array}$ & \\
\hline $\begin{array}{l}\text { Many of the places I need to get to regularly are within walking } \\
\text { distance of my home. }\end{array}$ & \\
\hline $\begin{array}{l}\text { Many of the places I need to get to regularly are within biking distance } \\
\text { of my home. }\end{array}$ & \\
\hline I have a bicycle at home that works that I could ride if I wanted to. & \\
\hline I don't have time to use public transit instead of driving. & \\
\hline I don't have time to walk places instead of driving. & \\
\hline I don't have time to bike places instead of driving. & \\
\hline The organization of my everyday life requires a high level of mobility. & \\
\hline
\end{tabular}




\subsection{TRAVEL BEHAVIOR AND INTENTIONS QUESTIONS}

\section{Included on all surveys}

\begin{tabular}{|c|c|}
\hline Questions & Potential Responses \\
\hline $\begin{array}{l}\text { Now I have some questions about your daily travel in } \\
\text { the future. }\end{array}$ & \\
\hline $\begin{array}{l}\text { How likely is it that in the next few weeks you will use } \\
\text { alternative modes of transportation instead of driving } \\
\text { your car for everyday travel. Are you... }\end{array}$ & \multirow{5}{*}{$\begin{array}{l}\text { Very Unlikely } \\
\text { Somewhat Unlikely } \\
\text { Neither Likely Nor Unlikely } \\
\text { Somewhat Likely } \\
\text { Very Likely } \\
\text { Not Applicable, I Do Not } \\
\text { Drive } \\
\text { Don't Know } \\
\text { Refused }\end{array}$} \\
\hline $\begin{array}{l}\text { How likely is it that in the next few weeks you will use } \\
\text { TriMet instead of the car for everyday travel. Are you... }\end{array}$ & \\
\hline $\begin{array}{l}\text { How likely is it that in the next few weeks you will walk } \\
\text { instead of driving your car for everyday travel. }\end{array}$ & \\
\hline $\begin{array}{l}\text { How likely is it that in the next few weeks you will bike } \\
\text { instead of driving your car for everyday travel. }\end{array}$ & \\
\hline $\begin{array}{l}\text { How likely is it that in the next few weeks you will } \\
\text { reduce how much you drive your car for everyday } \\
\text { travel. }\end{array}$ & \\
\hline
\end{tabular}

\begin{tabular}{|l|l|}
\hline Questions & \multicolumn{1}{|c|}{ Potential Responses } \\
\hline $\begin{array}{l}\text { In the past month how often have you taken TriMet to } \\
\text { get somewhere? }\end{array}$ & $\begin{array}{l}\text { Never } \\
\text { Less than once a month } \\
\text { In the past month how often have you walked from your } \\
\text { home to destinations nearby, such as shops, restaurants, } \\
\text { work, school, or errands? Do not include walking } \\
\text { around the neighborhood just for exercise. }\end{array}$ \\
$\begin{array}{l}\text { In the past month how often have you ridden a bicycle } \\
\text { from your home to destinations nearby, such as shops, } \\
\text { restaurants, work, school, or errands? Do not include } \\
\text { biking around the neighborhood just for exercise. }\end{array}$ & $\begin{array}{l}\text { More than once a week } \\
\text { Don't Know } \\
\text { Refused }\end{array}$ \\
\hline
\end{tabular}

About how many miles per week do you drive your car?

INTERVIEWER NOTE: We're only interested in personal travel (not business travel). Personal Travel includes ZipCar usage.

Enter 0000-2000 miles

Not Applicable, I Do Not Drive

Don't know

Refused

Which of these five statements is most reflective of your current walking behavior? We're interested in your walking for daily travel, for example to destinations nearby, such as shops, restaurants, work, school, or errands, rather than walking around the neighborhood just for exercise.

Don't currently walk and have no intention to in the next 6 months.

Don't currently walk but intend to within 1 month. 
Don't currently walk but intend to in the next 6 months.

I've regularly walked for daily travel for less than 6 months.

I've regularly walked for daily travel for more than 6 months.

Don't Know

Refused

Which of these five statements is most reflective of your current bicycle riding behavior?

Please stop me when I reach the option that fits you best.

Don't currently ride a bike and have no intention to in the next 6 months.

Don't currently ride a bike but intend to within 1 month.

Don't currently ride a bike but intend to in the next 6 months.

I've regularly ridden a bike for less than 6 months.

I've regularly ridden a bike for more than 6 months.

Don't Know

Refused

Which of the five items is most reflective of your current TriMet use?

Don't currently use TriMet and have no intention to begin in the next 6 months.

Don't currently use TriMet but intend to begin within 1 month.

Don't currently use TriMet but intend to begin in the next 6 months.

I've regularly used TriMet for less than 6 months.

I've regularly used TriMet for more than 6 months.

Don't Know

Refused

Which of the five items is most reflective of your current driving behavior? IFI currently drive and have no intention to reduce it within the next 6 months.

I currently drive but intend to reduce it within 1 month.

I currently drive but intend to reduce it within the next 6 months.

I started to reduce it in the last 6 months.

I have reduced it for more than 6 months.

Not Applicable, I Do Not Drive

Don't Know

Refused

Do you think you are driving alone to places more often, less often, or about the same number of times each month as you were three months ago? [NOTE: City of Portland survey question]

More Often

About the Same

Less Often

Not Applicable, I Do Not Drive

Don't Remember/Don't Know

Refused

If the respondent answered "Less Often" post-surveys include these follow-up questions: 
Is the recent increase in gas prices a reason you are driving less often?

No

Yes

Don't Know

Refused

[If yes...] Would you say it is...

The ONLY reason you are driving less

Not the only, but the MAIN reason you are driving less

One of many reasons you are driving less

Don't Know

Refused

\subsection{SMARTTRIPS QUESTIONS}

\section{Questions included on the Southwest post-survey}

Earlier this year, the City of Portland mailed an order form to every household in your neighborhood. The order form provided an opportunity for you to get information about transportation options such as walking and biking in your neighborhood. Do you remember this mailer?

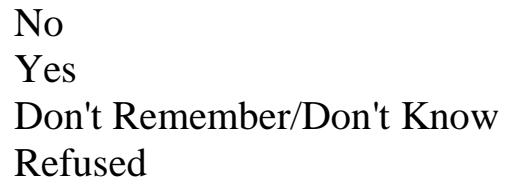

[If Yes...] Did you order any materials from the form?

No

Yes

Don't Remember/Don't Know

Refused

During this summer, as part of the SmartTrips program, the City of Portland sponsored several walking and bicycling activites in your neighborhood, including Summer Cycle, Women on Bikes, Ten Toe Express, Senior Strolls, and other classes or clinics. Did you participate in any of these activities?

No

Yes

Don't Remember/Don't Know

Refused

[If Yes] Which of those activities did you participate in?

Summer Cycle

Women on Bikes

Ten Toe Express

Senior Strolls

Other (Please Describe) 
Don't Remember/Don't Know

Refused

Questions included on the Northeast post-survey

Two years ago, in 2006, the City of Portland mailed an order form to every household in your neighborhood. The order form provided an opportunity for you to get information about transportation options such as walking and biking in your neighborhood. Do you remember this mailer?

No

Yes

Don't Remember/Don't Know

Refused

[If Yes...] Did you order any materials from the form?

No

Yes

Don't Remember/Don't Know

Refused

The City of Portland has also sponsored walking and bicycling activities in your neighborhood, including Summer Cycle, Women on Bikes, Ten Toe Express, Senior Strolls, and other classes or clinics. Did you participate in any of these activities?

No

Yes

Don't Remember/Don't Know

Refused

[If Yes...] Which of those activities did you participate in?

Summer Cycle

Women on Bikes

Ten Toe Express

Senior Strolls

Other (Please Describe)

Don't Remember/Don't Know

Refused

\section{Questions included on the Southeat post-survey}

Last year, the City of Portland mailed an order form to every household in your neighborhood. The order form provided an opportunity for you to get information about transportation options such as walking and biking in your neighborhood. Do you remember this mailer?

No

Yes

Don't Remember/Don't Know

Refused

[If Yes...] Did you order any materials from the form?

No

Yes 
Don't Remember/Don't Know

Refused

As part of the SmartTrips program, the City of Portland has sponsored walking and bicycling activities in your neighborhood, including Summer Cycle, Women on Bikes, Ten Toe Express, Senior Strolls, and other classes or clinics. Did you participate in any of these activities?

No

Yes

Don't Remember/Don't Know

Refused

[If Yes...] http://www.software995.com/Which of those activities did you participate in?

Summer Cycle

Women on Bikes

Ten Toe Express

Senior Strolls

Other (Please Describe)

Don't Remember/Don't Know

Refused

\subsection{DEMOGRAPHIC QUESTIONS}

Included on all surveys, except questions denoted with * not included in Southwest postsurvey.

We're almost finished. The next few questions are for demographic purposes only.

How many, if any, cars, trucks, SUVs, or vans do you have at your residence?

Enter number of vehicles up to 20.

Refused

* Do you personally own at least one bike?

No

Yes

Don't Know

Refused

Including yourself, how many people live in your household?

One person

Two or more people (enter number)

Refused

How many, if any, children under the age of 18 live in your home?

ENTER NUMBER OF CHILDREN 0-20

Refused

* What is your age, please? 
ENTER AGE

Don't know

Refused

* And what is the last year of education you had the opportunity to complete?

Less than 12th grade (not a high school graduate)

High school graduate

Some college or other post-secondary education

College graduate

Some post-graduate

Master's degree or higher

Don't Know

Refused

* What racial or ethnic group do you belong to?

White or Caucasian

Black or African-American

Asian or Asian-American

American-Indian or Alaskan Native

Native Hawaiian or other Pacific Islander

Spanish, Hispanic, or Latino

Other (Please Specify)

Don't Know

Refused

* Please stop me when I reach the category that best describes your yearly total household income before taxes.

Less than $\$ 15,000$

$\$ 15,000$ to less than $\$ 25,000$

$\$ 25,000$ to less than $\$ 35,000$

$\$ 35,000$ to less than $\$ 50,000$

$\$ 50,000$ to less than $\$ 75,000$

$\$ 75,000$ to less than $\$ 100,000$

$\$ 100,000$ to less than $\$ 150,000$

$\$ 150,000$ or more

Don't Know

Refused

* One of the purposes of this study is to understand how your neighborhood may influence your travel. To do that accurately, could you please tell me the street intersection closest to your home? I want to assure you again that PSU will protect your confidentiality and privacy.

Enter First Street (i.e. SW 4th Ave.)

Enter Second Street (i.e. SW Market St.)

Don't Know

Refused 



\section{$\mathcal{S}$ O O T R R R C C}

P.O. Box 751

Portland, OR 97207

OTREC is dedicated to stimulating and conducting collaborative multi-disciplinary research on multi-modal surface transportation issues, educating a diverse array of current practitioners and future leaders in the transportation field, and encouraging implementation of 